\title{
Water quality assessment and geochemical processes in the unconfined coastal Boa Viagem Aquifer, Recife, NE Brazil
}

\author{
Thyego R. Silva*1,2 \\ Mariucha M. Correia de Lima ${ }^{1,2}$ \\ Teresa E. Leitão ${ }^{3}$ \\ Tiago Nunes Martins ${ }^{3,4}$ \\ Mateus S. Cezar de Albuquerque \\ ${ }^{1}$ Agência Pernambucana de Águas e Clima \\ Av. Cruz Cabugá 1111, Santo Amaro \\ Recife PE Brasil \\ CEP 50040-000 \\ ${ }^{2}$ Universidade Federal de Pernambuco \\ Departamento de Geologia/NEG-LABISE \\ Av. Acadêmico Hélio Ramos s/n \\ Cidade Universitária, \\ Recife PE Brasil \\ CEP 50740-550 \\ ${ }^{3}$ Laboratório Nacional de Engenharia Civil \\ Departamento de Hidráulica e Ambiente \\ Avenida do Brasil, 101 \\ Lisboa Portugal \\ ${ }^{4}$ Universidade de Lisboa \\ Instituto Superior Técnico \\ Av. Rovisco Pais, № 1 \\ Lisboa Portugal \\ 1049-00 \\ ${ }^{*}$ Corresponding author \\ rthyego@yahoo.com
}

\section{Copyright}

This is an open-access article distributed under the terms of the

Creative Commons Attribution License.

\section{RESUMO}

Um estudo hidroquímico foi realizado no Aquífero Quaternário, em Recife, Brasil. Amostras de água subterrânea foram coletadas em marçoabril de 2015, no início da estação chuvosa. Gráficos convencionais, razões iônicas, índices de saturação, mapeamento GIS e análises geoestatísticas e estatísticas multivariadas foram usados para avaliação da qualidade da água e para caracterizar os principais processos hidroquímicos que controlam a química das águas subterrâneas. A análise de agrupamento hierárquico/modo $\mathrm{Q}$ separou as amostras em três agrupamentos e cinco subconjuntos de acordo com suas semelhanças hidroquímicas e fácies. A Análise de Componentes Principais (PCA) foi empregada para as amostras de água subterrânea estudadas, onde um modelo de três fatores explica $80 \%$ da variação total dentro do conjunto de dados. Os resultados da PCA revelaram a influência da intrusão de água do mar, interação água-rocha e contaminação por nitrato. Os parâmetros físico-químicos de aproximadamente $30 \%$ das águas subterrâneas excedem as diretrizes da Organização Mundial da Saúde (OMS) para a qualidade da água potável. $\mathrm{O}$ nitrato foi encontrado em uma concentração > $10 \mathrm{mg} \mathrm{NO}_{3}{ }^{-} / \mathrm{L} \mathrm{em} \sim 21 \%$ dos poços e excedeu os valores de referência da OMS em um. A abordagem integrada indica a ocorrência dos principais processos hidrogeoquímicos que ocorrem no aquífero marinho raso ao aluvial como segue: 1) purificação progressiva da paleo-água remanescente do mar acompanhando troca catiônica em sedimentos finos, 2) interação águarocha (ou seja, dissolução de silicatos) e 3) contaminação pontual e difusa de águas residuais e dissolução de sulfato. Este estudo destaca com sucesso o uso de métodos geoquímicos clássicos, técnicas de GIS e análises estatísticas multivariadas (cluster hierárquico e análises de componentes principais) como ferramentas complementares para compreender os processos hidrogeoquímicos e sua influência no estado da qualidade da água subterrânea para ações de gestão, que poderiam ser usadas em aquíferos costeiros aluviais.

Palavras-chave: Aquífero marinho-aluvial Boa Viagem, avaliação da qualidade da água, processos hidrogeoquímicos, análises estatísticas multivariadas, análise GIS

\section{ABSTRACT}

A hydrochemical study was conducted on the Quaternary Aquifer, in Recife, Brazil. Groundwater samples were collected in March-April 2015, at the beginning of the rainy season. Conventional graphics, ionic ratios, saturation indices, GIS mapping, and geostatistical and multivariate statistical analyses were used to water quality assessment and to characterize the main hydrochemical processes controlling groundwater's chemistry. Q-mode hierarchical cluster analysis separated the samples into three clusters and five sub-clusters according to their hydrochemical similarities and facies. Principal Component Analysis (PCA) was employed to the studied groundwater samples where a three-factor model explains $80 \%$ of the total variation within the dataset. The PCA results 
revealed the influence of seawater intrusion, water-rock interaction, and nitrate contamination. The physico-chemical parameters of $\sim 30 \%$ groundwaters exceed the World Health Organization (WHO) guidelines for drinking water quality. Nitrate was found at a concentration $>10 \mathrm{mg}$ $\mathrm{NO}_{3}{ }^{-} / \mathrm{L}$ in $\sim 21 \%$ of the wells and exceeded WHO reference values in one. The integrated approach indicates the occurrence of the main major hydrogeochemical processes occurring in the shallow marine to alluvial aquifer as follow: 1) progressive freshening of remaining paleo-seawater accompanying cation exchange on fine sediments, 2) water-rock interaction (i.e., dissolution of silicates), and 3) point and diffuse wastewater contamination, and sulfate dissolution. This study successfully highlights the use of classical geochemical methods, GIS techniques, and multivariate statistical analyses (hierarchical cluster and principal component analyses) as complementary tools to understand hydrogeochemical processes and their influence on groundwater quality status to management actions, which could be used in similar alluvial coastal aquifers.

Keywords: Marine-alluvial Boa Viagem aquifer, water quality assessment, hydrogeochemical processes, multivariate statistical analyses, GIS analysis

\section{INTRODUCTION}

The world's population is growing by about 80 million people per year (UNESCO 2015). This dramatic fast growth in population is usually accompanied by changes in soil and land use as well as increased water demand for human and animal consumption, agriculture, industries, etc. (BORETTI; ROSA, 2019). This increase is first met by surficial water reserves, which no longer are sufficient to meet the new needs, either by insufficient quantity or quality of waters that are more vulnerable to anthropic contamination. Water supply usually relies on groundwater, the most valuable long-term reserve mainly in arid and semi-arid areas, supporting human life by providing two billion people with drinking water and food production (e.g. ALLAN, 1998; JASECHKO et al., 2014). Therefore, the exploitation of groundwaters resources requires a thorough knowledge of hydrogeology and hydrogeochemistry for the integrated management and sustainable use (CUSTODIO, 2010). In such a way, groundwater should be protected to maintain highquality and quantity levels, as well as to regulate exploited volume (e.g. ALMEIDA et al., 2016).

One of the most important processes which decrease groundwater quality around the world is salinization primarily associated with marine sources (e.g. marine transgressions, seawater flooding and trapping, marine spray). Secondary processes have been attributed to continental sources (e.g. evaporation, dissolution, etc.) and anthropogenic activities (e.g. return irrigation flows, sewage infiltration) (VENGOSH; ROSENTHAL, 1994; BIANCHINI et al., 2005; CUSTODIO, 2010; CRUZ-
FUENTES et al., 2014; LADESMA-RUIZ et al., 2015; MIRZAVAND et al., 2020 and references therein).

The chemical signature imprinted on groundwater in sedimentary basins is largely influenced by long-term hydrological processes (e.g. MOYA et al., 2015). Understanding the main constraining hydrochemical processes (such as seawater intrusion, water-rock interactions, ion-exchange, water mixing, dissolution, and precipitation, etc.) operating in groundwater is crucial to managing these resources (e.g. MONTETY et al., 2008; CARTWRIGHT et al., 2008; CLOUTIER et al., 2010; MONJEREZI et al., 2011; MOYA et al., 2015; HAN et al., 2011; LI et al., 2018).

Multivariate statistical analysis techniques, such as principal component analysis (PCA) and hierarchical cluster analysis (HCA), have been widely used to assess the main hydrochemical processes operating in groundwater (GÜLER et al., 2004, 2012; CLOUTIER et al., 2008; KAZAKIS et al., 2017; RAKOTONDRABE et al., 2018; SILVA et al., 2021 to cite few). Multivariate statistical associations do not establish cause and consequence (GÜLER et al., 2002). However, statistical techniques reveal relationships between the data components, so that important information may be retained, while noise is discarded (MENCIÓ; MAS-PLA, 2008; MOYA et al., 2015; JOLLIFFE; CADIMA, 2016), which assist in generating hypothesis for the interpretation of hydrochemical processes (GÜLER et al., 2002). The statistical techniques combined with classical geochemical methods 
have been shown a long time as an objective means to classify and interpret complex datasets (GÜLER et al., 2002).

In this paper, hydrochemical data (1) was used to assess the water quality status of the Quaternary Aquifer (also known as Boa Viagem aquifer; COSTA et al., 1994) at Recife,

\section{STUDY AREA}

\subsection{GENERAL FEATURES}

The study area is located in the Recife municipality, Northeastern Brazil, covering an area of $218 \mathrm{~km}^{2}$ along the Atlantic Ocean. Recife has a hot and tropical climate, with an annual average rainfall of circa $2400 \mathrm{~mm}$ (VISEU et al., 2016; data from 1984 to 2013) where two marked seasons are identified; the rainy season lasts from March to August (average $230 \mathrm{~mm} / \mathrm{month}$ ) and the dry period lasts from September to February (average 68 $\mathrm{mm} / \mathrm{month}$ ). At the Recife station (INMET-

\subsection{GEOLOGY AND HYDROGEOLOGY}

The sediments deposited at the Recife coastal plain are highly heterogeneous in terms of lithology and dominated of intercalated fossiliferous-rich sandstones, shales, mudstones, siltstones, which overlying indistinctly the formations from the Pernambuco and Paraíba basins (e.g. Cabo and Beberibe formations), developed on Quaternary shallow marine to alluvial-estuarine environments (Fig. 1). They comprise beachridge terraces of Pleistocene $(120,000$ years B.P.) and Holocene (5,100 years B.P.) age associated with the penultimate and ultimate transgressions that reach maximums of $8-10$, and 5 meters above the current sea level (m.a.s.l), respectively, as well lagoonal deposits (4,400-8,300 years B.P.), sandstone and coral reefs with ages spanning from 1770 to 5170 years B.P, and finally alluvial, freshwater

\section{MATERIALS AND METHODS}

\subsection{PHYSICAL-CHEMICAL ANALYSIS}

A hydrochemical campaign was carried out in 2015 at end of the dry season in the wells installed in Boa Viagem Aquifer. All samples were collected directly at the wellhead after pumping of three well volumes of water in the well casing to obtain stationary conditions ensuring representative samples. Some wells have long screened intervals, and, therefore,
Brazil, and; (2) to unravel the main hydrochemical processes operating on through using classical geochemical methods (Such as Piper, Stiff, Gibbs, HFE-D, ionic ratios, etc.) integrated with multivariate statistical analyses (PCA and HCA).

PE), the mean annual temperature is $25.9{ }^{\circ} \mathrm{C}$ presenting a maximum value that reaches 30.9 ${ }^{\circ} \mathrm{C}$ in March and a minimum value of $20.9{ }^{\circ} \mathrm{C}$ in August. The area is characterized by many rivers where the Beberibe and Capibaribe, which flow from West to East, are the most relevant regionally. A semidiurnal mesotidal regime with tides up to $2.7 \mathrm{~m}$ (BRAZILIAN NAVY, 2020) occurs being tide penetration recorded in the main rivers up to $12 \mathrm{~km}$ (PAIVA, 2004).

swamp, and mangrove swamp deposits of Holocene age (DOMINGUEZ et al., 1990; SUGUIO et al., 2013). At the Boa Viagem beach, where these sediments are better individualized the corresponding aquifer was named "Boa Viagem" by Costa et al. (1994, 1998). This aquifer occurs under unconfined conditions with low to moderate hydraulic properties (median yield of $5 \mathrm{~m}^{3} / \mathrm{h}$; COSTA et al., 1998, 2002). The study area is densely populated and the natural recharge areas for the Boa Viagem Aquifer have been limited (PAIVA et al., 2015) due to impermeabilization tied to urban expansion. The average depth of this aquifer is about $40 \mathrm{~m}$. It is largely used for domestic supply, due to the low distance to the groundwater table and the low well drilling costs.

water samples are from a relatively large section of the aquifer. Groundwater samples were collected in HDPE bottles washed with the water well and filled to overflowing.

Water analyses were carried out according to the standard procedures of APHA (2012) and EPA (2007). Measurements of electrical conductivity (EC) and $\mathrm{pH}$ were conducted 
following $2510 \mathrm{~B}$ and $4500 \mathrm{~B}$ methods, respectively. The amount of total dissolved solids (TDS) was determined gravimetrically by evaporation. Alkalinity was shortly measured after sampling by titration and Gran's method (APHA 2320B). $\mathrm{SO}_{4}{ }^{2-}$ was determined by the turbidimetric method $\left(4500-\mathrm{SO}_{4} \mathrm{D}\right) . \mathrm{NO}_{3}{ }^{-}, \mathrm{Fe}$, and $\mathrm{F}-$ were determined by spectrophotometric method (4500- $\mathrm{NO}_{3} \mathrm{~B}, 3500-\mathrm{Fe} \mathrm{B}$, and $4500-\mathrm{F}$ $\mathrm{D}$, respectively) whereas $\mathrm{Cl}^{-}$was determined by iodometric method (4500-Cl B). $\mathrm{Ca}^{2+}, \mathrm{Mg}^{2+}$, and $\mathrm{TH}$ (total hardness) analyses were performed by titration method (3500-Ca B, $3500-\mathrm{Mg} \mathrm{B}$, and $2340 \mathrm{C}$, respectively). $\mathrm{Na}^{+}$and
$\mathrm{K}^{+}$by Flame Atomic Emission Spectrometry (3500-Na B and 3500-K B). Ba ${ }^{2+}$ was analyzed by inductively coupled plasma-atomic emission spectrometry (ICP-AES) method $(6010 \mathrm{C})$. The electro-neutrality parameter of analysis $\left(100 *\left[\sum z . m c-\sum z \cdot m a\right] /\left[\sum z . m c+\sum z \cdot m a\right]\right.$; where $z$ is the ionic valence, and $m c$ and $m a$ the molarity of cationic and anionic species, respectively (FREEZE; CHERRY 1979; APPELO; POSTMA 2005) was less than or equal to $\pm 5 \%$ for $74 \%$ of the samples. $26 \%$ of samples had electro-neutrality between 5 and $10 \%$ with an anionic deficit. Chemical analyses are portrayed in Table 1.

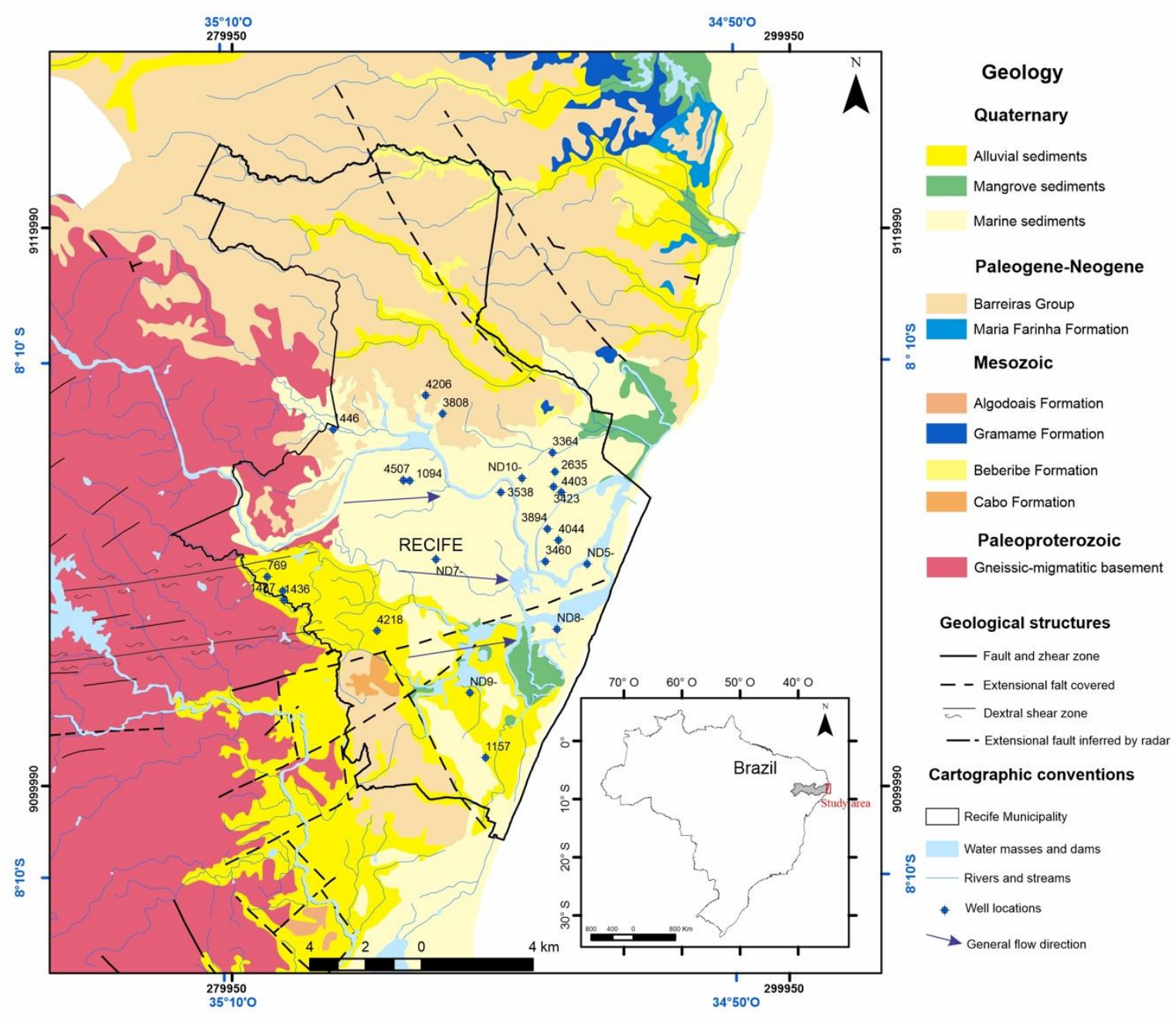

Figure 1

Geologic map of the studied area showing the sample sites.

\subsection{STATISTICAL ANALYSIS}

All data were subjected to multivariate statistical analyses (MSA) using the statistical software package SPSS 20 for Windows ${ }^{\circledR}$ (SPSS Corp., USA). Eleven variables were used in the evaluation ( $\mathrm{pH}, \mathrm{EC}, \mathrm{TDS}, \mathrm{Ca}^{2+}, \mathrm{Mg}^{2+}, \mathrm{K}^{+}$, $\mathrm{Na}^{+}, \mathrm{Cl}^{-}, \mathrm{SO}_{4}{ }^{2-}, \mathrm{HCO}_{3}^{-}$, and $\left.\mathrm{NO}_{3}^{-}\right)$. Data screening showed that the data are highly skewed positively (except $\mathrm{pH}$ ). Therefore, the data were log-transformed so that they correspond more closely to normally distributed data. Finally, all the variables were standardized by calculating their standard scores $(z(i)$-scores 
$=(x i-x) / s ;$ where $z(i)=$ standard score of the sample $\mathrm{i} ; \mathrm{xi}=$ sample value $\mathrm{i} ; \mathrm{x}=$ mean; $\mathrm{s}=$ standard deviation). Two well-proven MSA were performed in the studied physicalchemical variables. Principal component analysis (PCA) and Q-mode Hierarchical Custer Analysis (HCA) were used, respectively, to data reduction revealing the most important components contributing to the data structure responsible for the total variance within the data

\subsection{GIS AND GEOSTATISTICAL ANALYSIS}

ArcGIS software (v. 10.6) was used to perform GIS analysis and geostatistical modeling. The inverse distance weighting (IDW) model for geospatial interpolation was employed and geostatistical surfaces were validated by testing an ordinary Kriging model, which offered similar results. Besides, IDW is one of the most applied and deterministic

\subsection{SATURATION INDICES}

Saturation Indices $[\mathrm{SI}=\log (\mathrm{IAP} / \mathrm{K})$, where IAP is the ion activity and $K$ equilibrium constant] was computed to calcite, aragonite, dolomite, gypsum, anhydrite, and halite using (e.g. HELENA et al., 2000; LIU et al., 2003; JOLLIFFE; CADIMA 2016), and to partitioning the groundwaters into sites groups (clusters) presenting similar characteristics (e.g. GÜLER et al., 2002; SINGH et al., 2004; CLOUTIER et al., 2008). HCA was set by Ward's method and the similarities among samples were measured by the Euclidean distance.

interpolation techniques in sciences (e.g. SINGH et al., 2017; RAKOTONDRABE et al., 2018), which is based on nearby known locations and use the inverse of its distance from the interpolation point and is relatively simpler to apply when compared with other interpolators.

the AQUACHEM PHREEQC interface (WATERLOO HYDROGEOLOGIC, INC; PARKHURST; APPELO, 2013) to check if precipitation could occur.

\section{RESULTS AND DISCUSSION}

\subsection{HYDROCHEMICAL DATA: GENERAL CHARACTERIZATION}

Table 2 summarizes the statistical variation of the analyzed parameters, which are shown in Fig. 2, while Fig. 3 refers to their geographical distribution. The variations of physical variables show that $\mathrm{pH}$ values ranged from 5.3 to 7.8 (acid to slightly alkaline) with four samples below the permissible limit for drinking water described by the World Health Organization standards (WHO 1996, 2011). Color and turbidity are relatively related to each other and the highest values of one associated with the other. They varied from 3 to $50 \mathrm{TCU}$ (true color unit) and 0.2 to $99.3 \mathrm{NTU}$ (nephelometric turbidity units), with five and six samples above WHO guidelines, respectively. EC varied from 179 to 1406 $\mu \mathrm{S} / \mathrm{cm}$ with only one sample above the permissible limits (sample 3460; $\mathrm{EC}=4,128$ $\mu \mathrm{S} / \mathrm{cm}$ ) for human consumption (average 703 $\mu \mathrm{S} / \mathrm{cm}$; std deviation $=824 \mu \mathrm{S} / \mathrm{cm}$ ). TDS ranged from 98 to 2,363 mg/L (average $413 \mathrm{mg} / \mathrm{L}$; std deviation $=473$ ). Only one sample presents TDS above WHO standards. $\mathrm{Ca}^{2+}, \mathrm{Mg}^{2+}, \mathrm{TH}$, and $\mathrm{K}^{+}$varied from 3.2 to $76.8,1$ to $54.7,16$ to $345 \mathrm{mg} / \mathrm{L}$, and 2.3 to $23.8 \mathrm{mg} / \mathrm{L}$, respectively, all of these within WHO limits. $\mathrm{Na}^{+}$shows values varying from 18.2 to $736 \mathrm{mg} / \mathrm{L}$, with a mean of 95.77 and a standard deviation of 149.22. Two samples have fallen above the WHO permissible limit. $\mathrm{Cl}^{-}$ranged from 21.3 to $1,075 \mathrm{mg} / \mathrm{L}$ (mean of $137 \mathrm{mg} / \mathrm{L}$; std dev = 222.55) and only three samples crossed the WHO threshold. $\mathrm{HCO}_{3}{ }^{-}$and $\mathrm{SO}_{4}{ }^{2-}$ ranged from 2.9 to 271 and 0.06 to $196.9 \mathrm{mg} / \mathrm{L}$, respectively. $\mathrm{NO}_{3}{ }^{-}$varied from 0.06 to $207 \mathrm{mg} / \mathrm{L}$ (median: 2.21). $100 \%$ of samples are within the WHO limit for $\mathrm{HCO}_{3}{ }^{-} \mathrm{SO}_{4}{ }^{2-}$, and $\mathrm{NO}_{3}{ }^{-}$, except to $\mathrm{NO}_{3}{ }^{-}$(short-term exposure $=50 \mathrm{mg} / \mathrm{L} ;$ WHO 2011) in one sample (\#ND8-). A guideline value of $0.2 \mathrm{mg} / \mathrm{L}$ for nitrate ion associated with longterm exposure was derived in the addendum to the WHO Guidelines, which we take as threshold evidence that the studied groundwaters exceed. The few groundwater samples analyzed for $\mathrm{F}^{-}$and $\mathrm{Ba}^{2+}$ varied from 0.19 to 0.86 and 0.06 to $0.53 \mathrm{mg} / \mathrm{L}$, respectively, within the WHO limit. Finally, Fe ranged from 0.01 to $2.7 \mathrm{mg} / \mathrm{L}$ (mean 0.44; std dev $=0.75$ ), with six samples exceeding the WHO guideline value. At levels exceeding $0.3 \mathrm{mg} / \mathrm{L}$, iron in water 
causes stains plumbing fixtures and laundry. High color values in some wells are related to high $\mathrm{Fe}$ contents and due to the presence of

\subsection{HIERARCHICAL CLUSTER ANALYSIS}

Q-mode HCA was applied to the 23 studied samples. The output dendrogram was analyzed and based on a visual observation a phenon line was drawn at a linkage distance of 7 (re-scaled distance). It resulted in the identification of three clusters and five sub-clusters (Fig.4; Table 3). TDS represents a distinguishing factor among these clusters/sub-clusters. Cluster $1 b$ samples present the lowest TDS values (average $121 \mathrm{mg} / \mathrm{L}$ ) followed by Cluster 1a (average 185 $\mathrm{mg} / \mathrm{L}$ ). Cluster 2 samples have intermediate TDS values (average $300 \mathrm{mg} / \mathrm{L}$ ) followed by clusters 3a with an average TDS of $594 \mathrm{mg} / \mathrm{L}$ up to cluster $3 \mathrm{~b}$ samples that present the highest TDS values (average $1186 \mathrm{mg} / \mathrm{L}$ ). Furthermore, the mean concentration Stiff diagram for each cluster/sub-cluster evidence the good results

\subsection{PRINCIPAL COMPONENT ANALYSIS}

Factor analysis was applied to the eleven selected variables providing satisfactory results. The Kaiser, Meyer, Olkin (KMO) measure of sampling adequacy shows a value of 0.670 that is statistically significant and Bartlett's sphericity test carried out on the correlation matrix reveals a calculated $\chi^{2}=296$ with a significance $<0.000$ and 55 degrees of freedom [df], thus evidencing that PCA can achieve a significant reduction of the dimensionality of the original data set. A varimax rotation was used to "clean up" the main parameters (maximize the variance, e.g. HELENA et al., 2000) influencing the variation, and the scree plot and the Kaiser criterion (KAISER, 1958) were used to retain only factor components with eigenvalues higher than one. The principal components explain $80.40 \%$ of the variance. The first three components explain $39.85 \%$, $21.56 \%$, and $18.99 \%$ of the variance, respectively. Component 1 explains the majority of the variance and is marked by strong positive loadings on $\mathrm{Cl}^{-}, \mathrm{Na}^{2+}, \mathrm{K}^{+}, \mathrm{Mg}^{2+}, \mathrm{EC}$, and TDS. Component 2 is characterized by strong positive loadings on $\mathrm{HCO}_{3}^{-}$and $\mathrm{pH}$. colored organic matter (primarily humic and fulvic acids) associated with the humus fraction of soil and lithology (e.g. WHO 2011).

rendering water facies with distinct geochemical characteristics (Fig. 4), thus achieving the purpose of the Q-mode HCA (e.g. GÜLER et al., 2004; CLOUTIER et al., 2008; WANG et al., 2018). In a similar approach to that of Güler et al. $(2002,2004)$ the defined cluster/sub-clusters of samples were plotted on a map to test the relationship between the statistically defined clusters of samples and geographic location and showed good correspondence between spatial locations and the statistical groups as determined by the HCA (Fig. 5). The close proximity to one sample to each other suggests common processes and/or flowpaths for these clusters of samples (e.g. THYNE et al., 2004).

Finally, component 3 shows highly positive loadings on $\mathrm{NO}_{3}{ }^{-}$and $\mathrm{SO}_{4}{ }^{2-}$ and moderate positive loading for $\mathrm{Ca}^{2+}$. Table 4 presents the results of the PCA with the loadings, eigenvalues, and associated variance. A map showing the spatial distribution of PC1, PC2, and PC3 scores is presented in Fig. 6. High scores (i.e., values ranging from 0.39 to 2.65 , 0.25 to 1.80 , and 0.08 to 2.61 , respectively) are generally observed at the coastal part of the study area for PC1, and from east to west in the central part of Recife for both PC2 and PC3.

Component 1 has been defined as the "salinity" component due to the association of the major solutes in groundwater. The highest loadings of chloride, which is a conservative tracer and is not altered by water-rock interaction indicate that this component (\#1) is mainly related to marine sources. Recife is located next to the Atlantic Ocean suggesting that $\mathrm{Cl}^{-}$origin may be attributed to sea-level variations. This interpretation is reinforced by the higher positive correlation between $\mathrm{Cl}^{-}$and $\mathrm{Na}^{+}(\mathrm{r}=0.93$; at $\mathrm{p}$-level $<0.000)$, which are the major ionic species in seawater. 


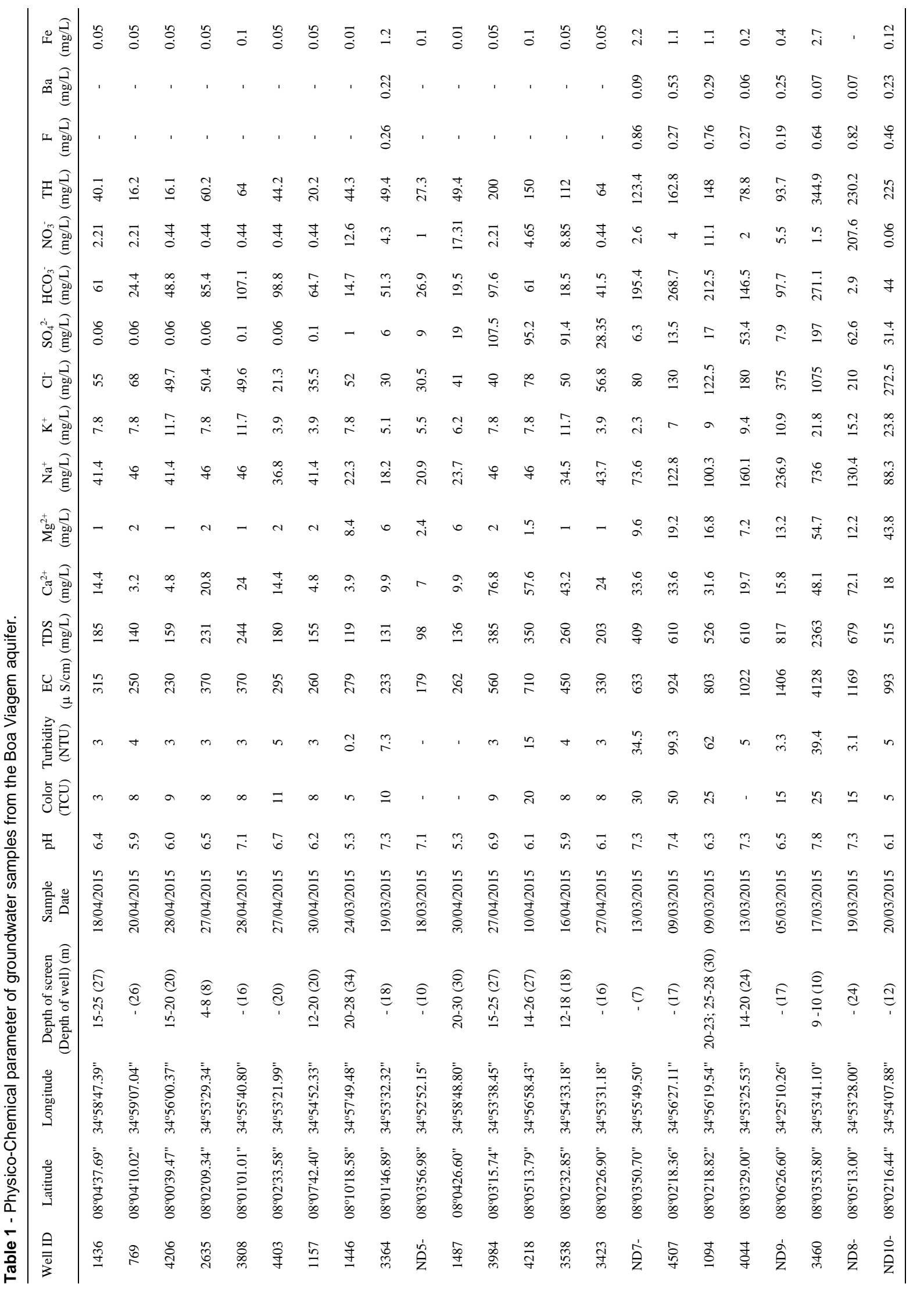




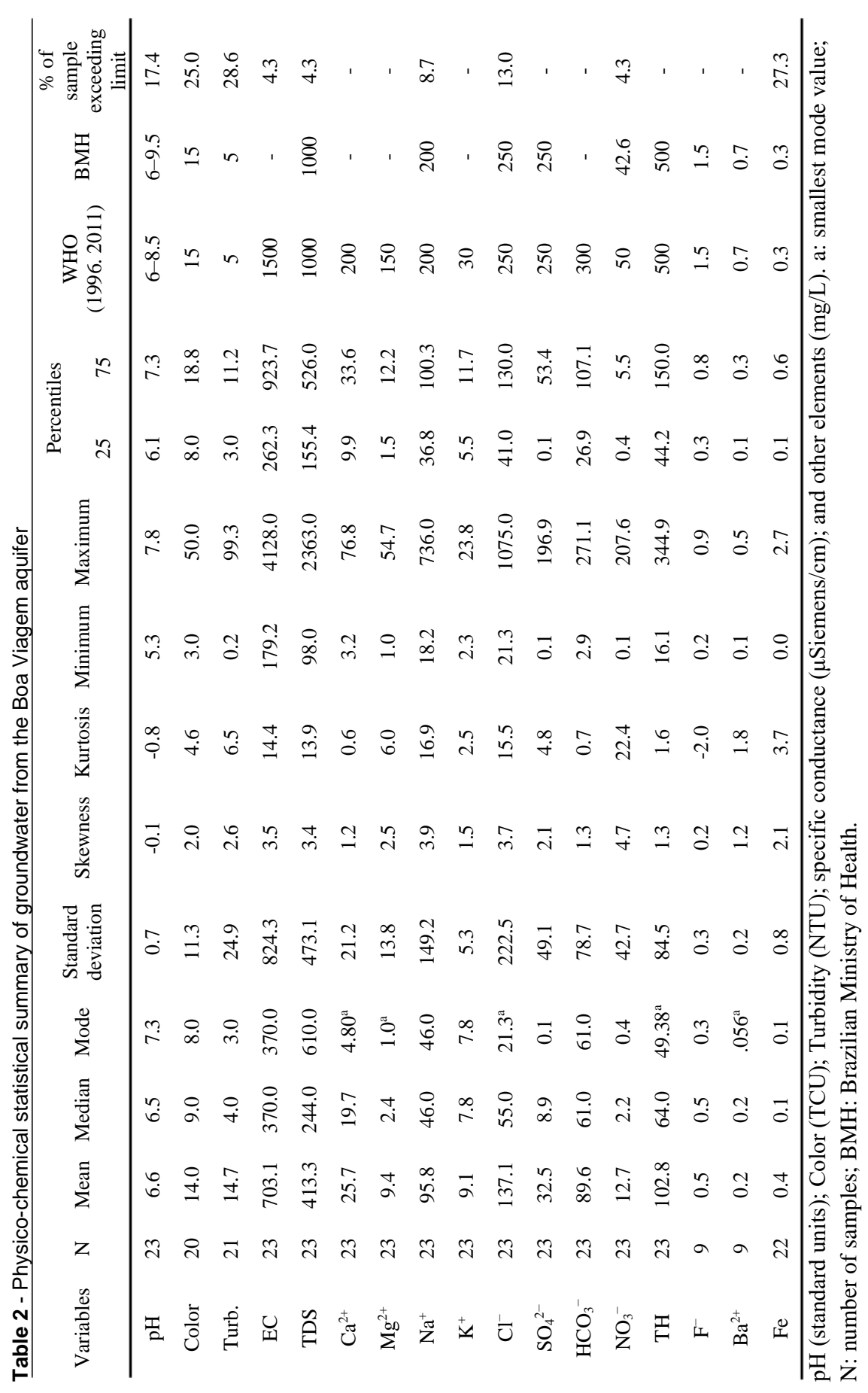

Component 2 is defined as the weathering component due to the reactions between the acidic $\mathrm{H}_{2} \mathrm{CO}_{3}$ and minerals triggered when the rain containing $\mathrm{CO}_{2}{ }^{2-}$ in equilibrium contacts the ground, which consumes the acid portion $\left(\mathrm{H}^{+}\right)$leaving the $\mathrm{HCO}_{3}^{-}$in solution. $\mathrm{Na}-$ (bi)carbonate waters are usually the product of long-term water-rock interaction with dissolution of carbonates (e.g. VENTURELLI et al., 2003). However, silicate minerals (such as feldspars, micas, amphiboles, and pyroxenes) by groundwater $\mathrm{H}_{2} \mathrm{CO}_{3}$ also produces major cations (such as $\mathrm{Na}^{+}, \mathrm{K}^{+}, \mathrm{Ca}^{2+}$ and $\mathrm{Mg}^{2+}$ ) and $\mathrm{HCO}_{3}^{-}$that could be explained using a generic equation (Eq. (1)) or by hydrolysis reactions of these minerals (e.g. Eq. (2): VENTURELLI et al., 2003; CARTWRIGHT; WEAVER 2004; NOSHADI; GHAFOURIAN, 2016; MUKHERJEE; SINGH, 2020 to cite few). This is in accordance with unpublished data, which indicate the predominance of quartz, feldspars, micas, and phyllosilicates.

(Cations)silicates $+\mathrm{H}_{2} \mathrm{CO}_{3} \rightarrow \mathrm{H}_{4} \mathrm{SiO}_{4}+\mathrm{HCO}_{3}{ }^{-}+$cations + solid products (usually clay minerals) (1)

$$
2 \mathrm{NaAlSi}_{3} \mathrm{O}_{8}+9 \mathrm{H}_{2} \mathrm{O}+\mathrm{H}_{2} \mathrm{CO}_{3} \rightarrow \mathrm{Al}_{2} \mathrm{Si}_{2} \mathrm{O}_{5}(\mathrm{OH})_{4}+2 \mathrm{Na}+2 \mathrm{HCO}_{3}{ }^{-}+4 \mathrm{H}_{4} \mathrm{SiO}_{4}
$$



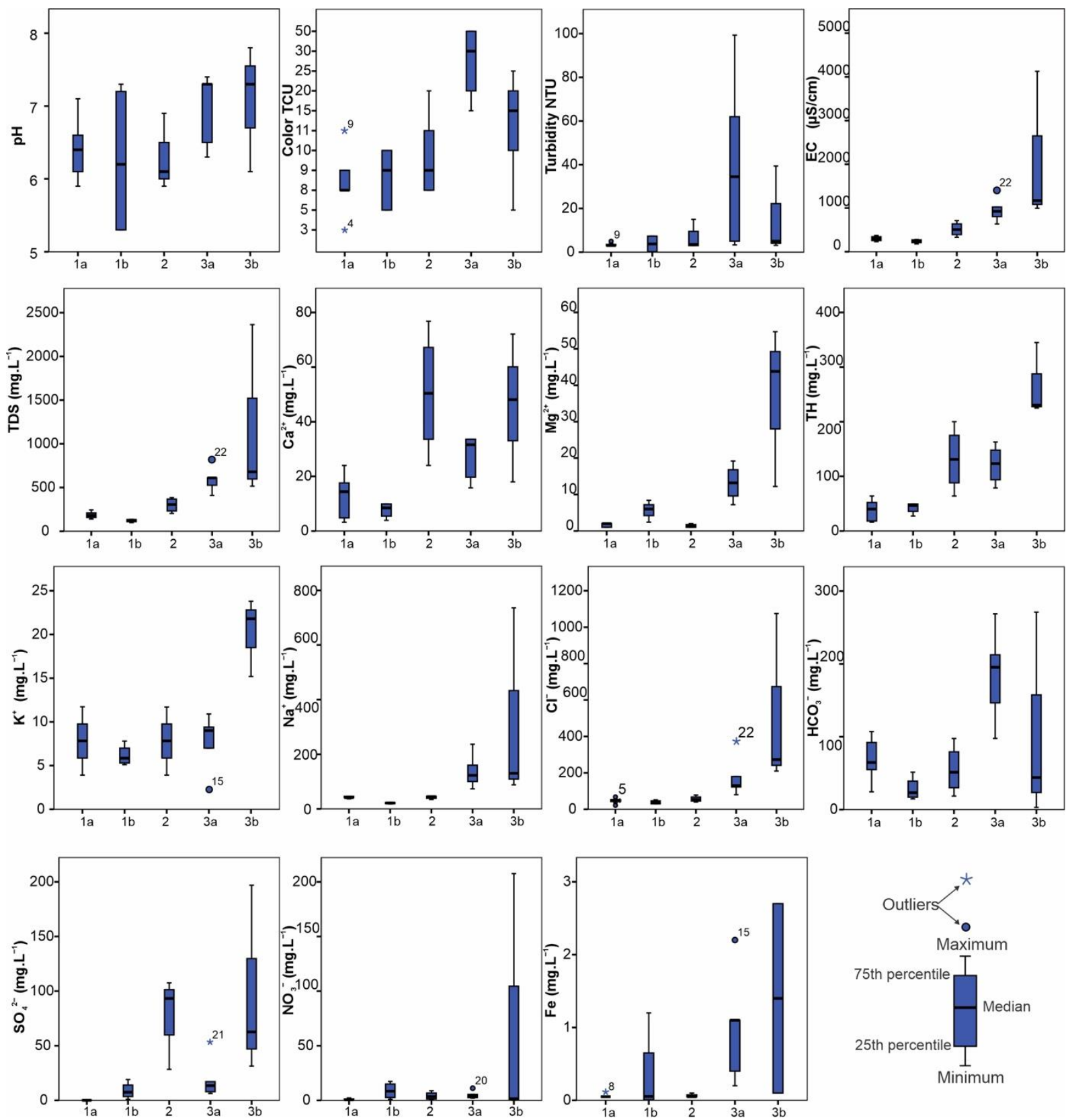

Box plots of the main physico-chemical parameters of groundwater labeled by clusters. The blue box represents the lower and upper quartiles with the median in middle. The circle indicates $1.5 \mathrm{x}$ interquartile range (IQR) (outliers), and whiskers indicate $3 \times$

Component 3 is regarded as the "contamination and seawater intrusion/sulfate dissolution" factor because of its highly positive loading on $\mathrm{NO}_{3}{ }^{-}$and moderate ones on $\mathrm{Ca}^{2+}$ and $\mathrm{SO}_{4}{ }^{2-}$. Nitrate can reach groundwater as a consequence of agricultural activity (e.g. LADESMA-RUIZ et al., 2015). However, wastewater disposal and oxidation of nitrogenous waste products in human and animal excreta, including septic tanks are possible sources to $\mathrm{NO}_{3}^{-}$, recurrent in densely populated areas (e.g. NOSHADI; GHAFOU-
RIAN, 2016; SINGH et al., 2017). It is probably the case of Recife, where its precarious public sanitary system covers only $35.2 \%$ of the wastewater collected (KRONEMBERGER, 2013). An increase in $\mathrm{SO}_{4}{ }^{2-}$ only occurs in cluster 2 and is probably attributed to couple seawater intrusion, which mainly increases $\mathrm{Cl}^{-}$, $\mathrm{SO}_{4}{ }^{2-}, \mathrm{Na}^{+}$as observed in experimental works, and sulfate dissolution which could be identified from obtained saturation indices below. 

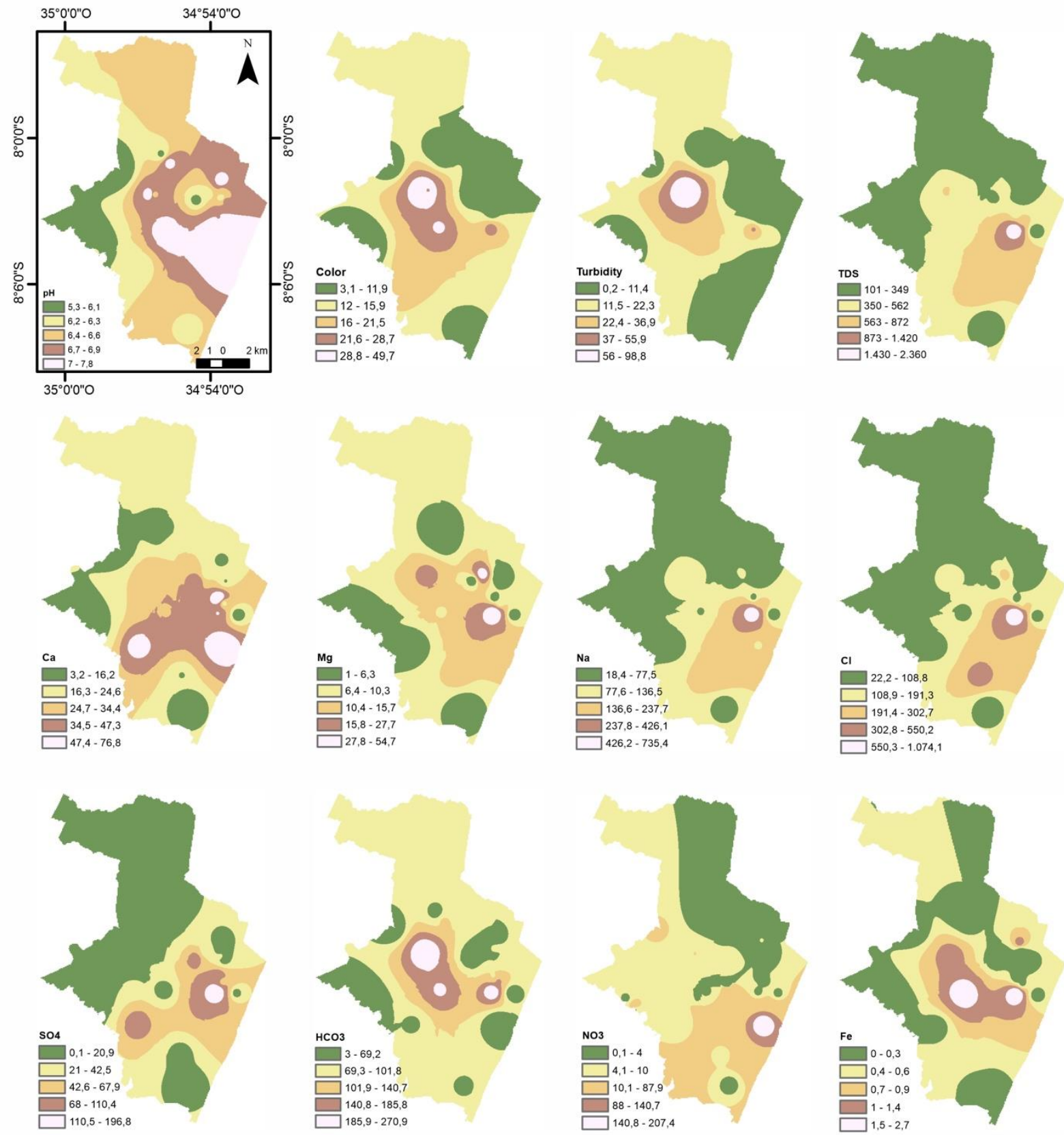

Figure 3

Spatial distribution of selected water quality parameters.

Table 3 - Mean water chemistry of cluster and sub-clusters as determined from Q-mode HCA.

\begin{tabular}{ccccccccccccc}
$\begin{array}{c}\text { Cluster/ } \\
\text { subclusters }\end{array}$ & $\begin{array}{c}\text { No of } \\
\text { samples }\end{array}$ & $\mathrm{pH}$ & $\begin{array}{c}\mathrm{EC} \\
(\mu \mathrm{S} / \mathrm{cm})\end{array}$ & $\begin{array}{c}\mathrm{TDS} \\
(\mathrm{mg} / \mathrm{L})\end{array}$ & $\begin{array}{c}\mathrm{Ca}^{2+} \\
(\mathrm{mg} / \mathrm{L})\end{array}$ & $\begin{array}{c}\mathrm{Mg}^{2+} \\
(\mathrm{mg} / \mathrm{L})\end{array}$ & $\begin{array}{c}\mathrm{Na}^{+} \\
(\mathrm{mg} / \mathrm{L})\end{array}$ & $\begin{array}{c}\mathrm{K}^{+} \\
(\mathrm{mg} / \mathrm{L})\end{array}$ & $\begin{array}{c}\mathrm{Cl}^{-} \\
(\mathrm{mg} / \mathrm{L})\end{array}$ & $\begin{array}{c}\mathrm{SO}_{4}{ }^{2-} \\
(\mathrm{mg} / \mathrm{L})\end{array}$ & $\begin{array}{c}\mathrm{HCO}_{3}{ }^{-} \\
(\mathrm{mg} / \mathrm{L})\end{array}$ & $\begin{array}{c}\mathrm{NO}_{3}{ }^{-} \\
(\mathrm{mg} / \mathrm{L})\end{array}$ \\
\hline 1 combined & 11 & 6.35 & 276.74 & 161.64 & 10.65 & 3.07 & 34.92 & 7.21 & 43.91 & 3.23 & 54.78 & 3.80 \\
$1^{\mathrm{a}}$ & 7 & 6.40 & 298.57 & 184.91 & 12.34 & 1.57 & 42.71 & 7.82 & 47.07 & 0.07 & 70.03 & 0.95 \\
$1 \mathrm{~b}$ & 4 & 6.25 & 238.53 & 120.90 & 7.68 & 5.70 & 21.28 & 6.15 & 38.38 & 8.75 & 28.10 & 8.80 \\
2 & 4 & 6.25 & 512.50 & 299.63 & 50.40 & 1.38 & 42.55 & 7.81 & 56.20 & 80.61 & 54.65 & 4.04 \\
3 combined & 8 & 6.60 & 1191.46 & 679.36 & 48.54 & 16.60 & 160.70 & 13.15 & 254.61 & 87.62 & 76.65 & 32.19 \\
$3^{\mathrm{a}}$ & 5 & 6.96 & 957.60 & 594.40 & 26.86 & 13.20 & 138.74 & 7.72 & 177.50 & 19.64 & 184.16 & 5.04 \\
$3 \mathrm{~b}$ & 3 & 7.07 & 2096.73 & 1185.67 & 46.07 & 36.90 & 318.23 & 20.27 & 519.17 & 96.97 & 106.00 & 69.72 \\
\hline
\end{tabular}




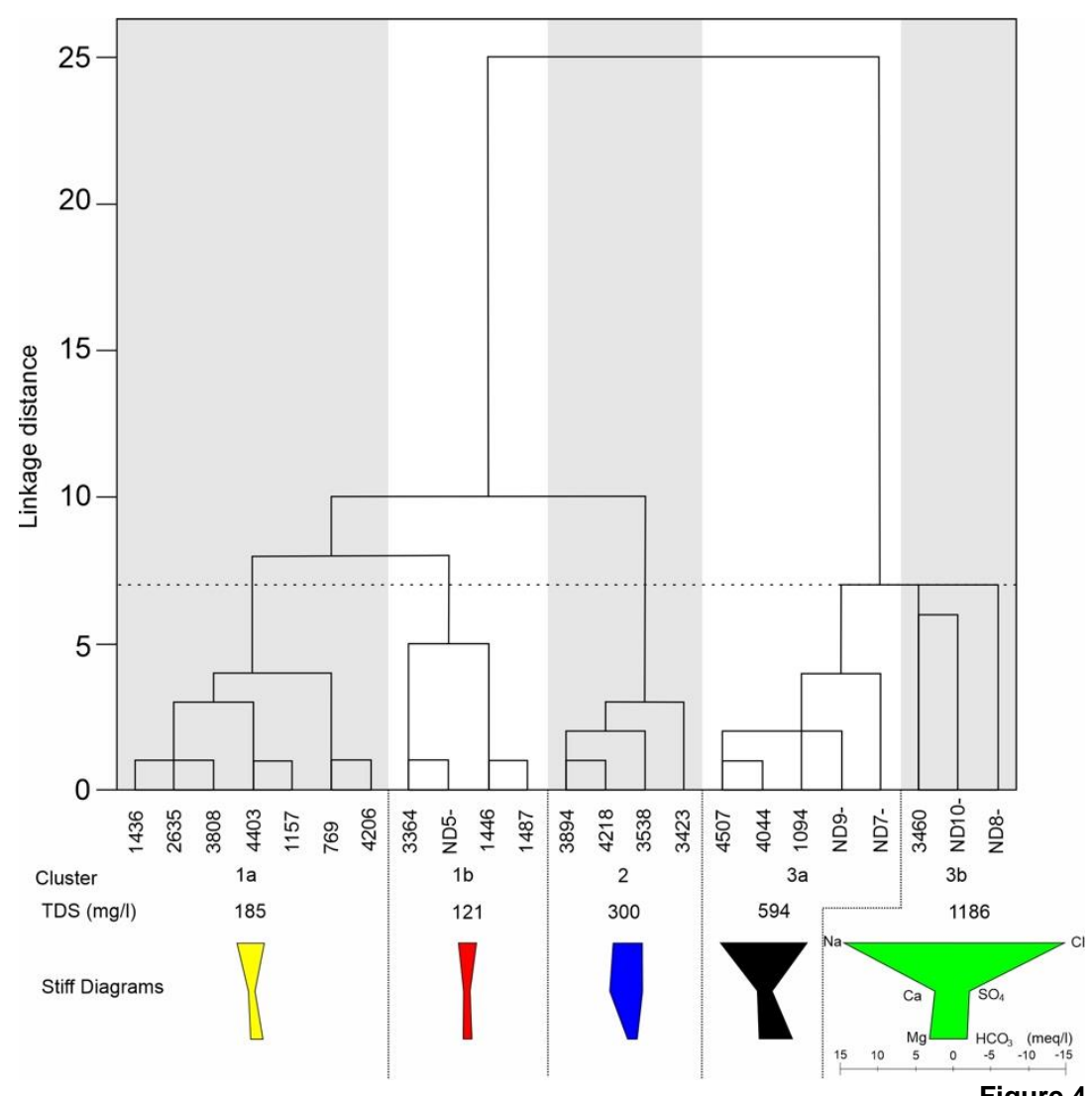

Figure 4

Dendrogram of Q-mode HCA for the groundwater samples and the median concentration Stiff plot of each cluster/sub-clusters. The dashed line represents a "phenon line".

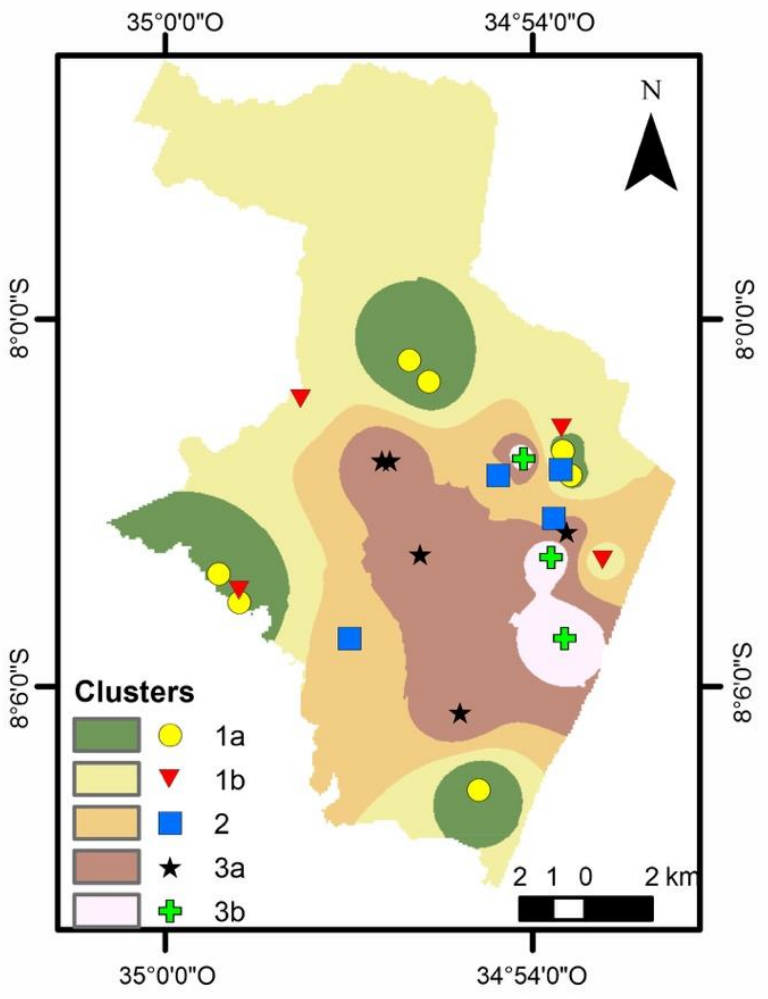

Figure 5

Map showing the spatial distribution of the statistically defined cluster/sub-clusters in the study area. 
Table 4 - Loadings, eigenvalue, and variance of the variables on the first three rotated PCs for whole data set.

\begin{tabular}{lccc}
\hline Parameters & \multicolumn{3}{c}{ Principal components } \\
& PC1 & PC2 & PC3 \\
\hline $\mathrm{pH}$ & 0.178 & $\mathbf{0 . 7 5 5}$ & 0.214 \\
$\mathrm{EC}$ & $\mathbf{0 . 8 3 5}$ & 0.407 & 0.339 \\
$\mathrm{TDS}$ & $\mathbf{0 . 7 9 9}$ & 0.487 & 0.316 \\
$\mathrm{Ca}^{2+}$ & 0.242 & 0.505 & $\mathbf{0 . 6 7 4}$ \\
$\mathrm{Mg}^{2+}$ & $\mathbf{0 . 7 3 8}$ & 0.155 & 0.191 \\
$\mathrm{Na}^{+}$ & $\mathbf{0 . 8 4 3}$ & 0.440 & 0.118 \\
$\mathrm{~K}^{+}$ & $\mathbf{0 . 8 0 7}$ & -0.258 & 0.024 \\
$\mathrm{Cl}^{-}$ & $\mathbf{0 . 9 4 6}$ & 0.192 & 0.158 \\
$\mathrm{SO}_{4}{ }^{2-}$ & 0.368 & 0.157 & $\mathbf{0 . 7 4 7}$ \\
$\mathrm{HCO}_{3}{ }^{-}$ & 0.138 & $\mathbf{0 . 8 4 1}$ & -0.322 \\
$\mathrm{NO}_{3}{ }^{-}$ & 0.046 & -0.302 & $\mathbf{0 . 7 9 8}$ \\
Eigenvalue & 4.383 & 2.372 & 2.089 \\
$\mathrm{Cumulative} \mathrm{eigenvalue}^{\circ}$ of variance & 4.383 & 6.755 & 8.844 \\
$\mathrm{Cumulative} \%$ of variance & 39.849 & 21.565 & 18.994 \\
\hline
\end{tabular}

Significant loadings in bold.
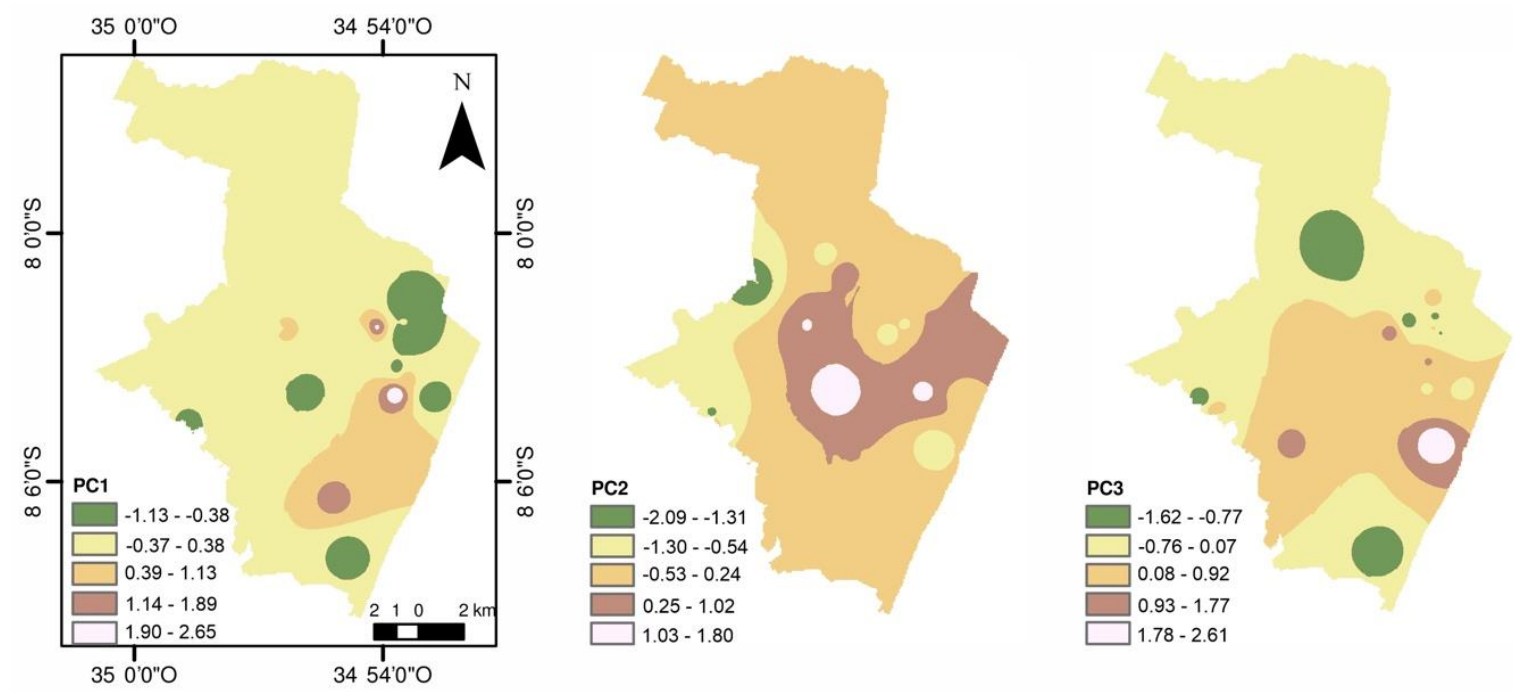

Figure 6

Spatial distribution of principal component scores for a PC1, b PC2, and c PC2.

\subsection{HYDROGEOCHEMICAL PROCESSES: FURTHER INSIGHTS USING CLASSIC GEOCHEMICAL METHODS}

The hydrogeochemical processes and major aquifer mechanisms were further identified using the geochemical samples in several

\subsubsection{SEAWATER INTRUSION OR FRESHENING}

The Recife coastal plain was subject to sealevel variations (e.g. SUGUIO et al., 2013) favoring past marine transgressions/regressions that produce intrusion and subsequent freshening phases, which has enhanced salinity on the Boa Viagem aquifer, as the ones experienced by many flat topographic areas classical diagrams and ionic ratios plots, which are discussed below.

around the world (e.g. KIM et al., 2017; LARSEN et al., 2017 to cite few).

In coastal aquifers that were impacted by seawater intrusion and/or freshening, geochemical reactions occur during the replacement of freshwater with seawater or vice-versa, resulting in a distinguishing chemical signature that 
can indicate intrusion/freshening phases. Hydrochemical Facies Evolution Diagram (HFE-D) approach was first developed in an alluvial aquifer of Vinaroz plain, Spain (Giménez-Forcada 2010, 2014), and has been proved a reliable diagram to identified intrusion/freshening phases (e.g. LE et al., 2020; PRUSTY et al., 2020), indicating the status of the aquifer in terms of advance or regression of the saline waters. Using the HFE$\mathrm{D}$, the data indicates that the coastal Boa Viagem aquifer is experiencing a freshening phase, although the majority of samples belonging to cluster 2 are situated in the intrusion phase (Fig. 7). Besides, during freshening, a process of direct exchange reactions takes place, and this process is further discussed below.

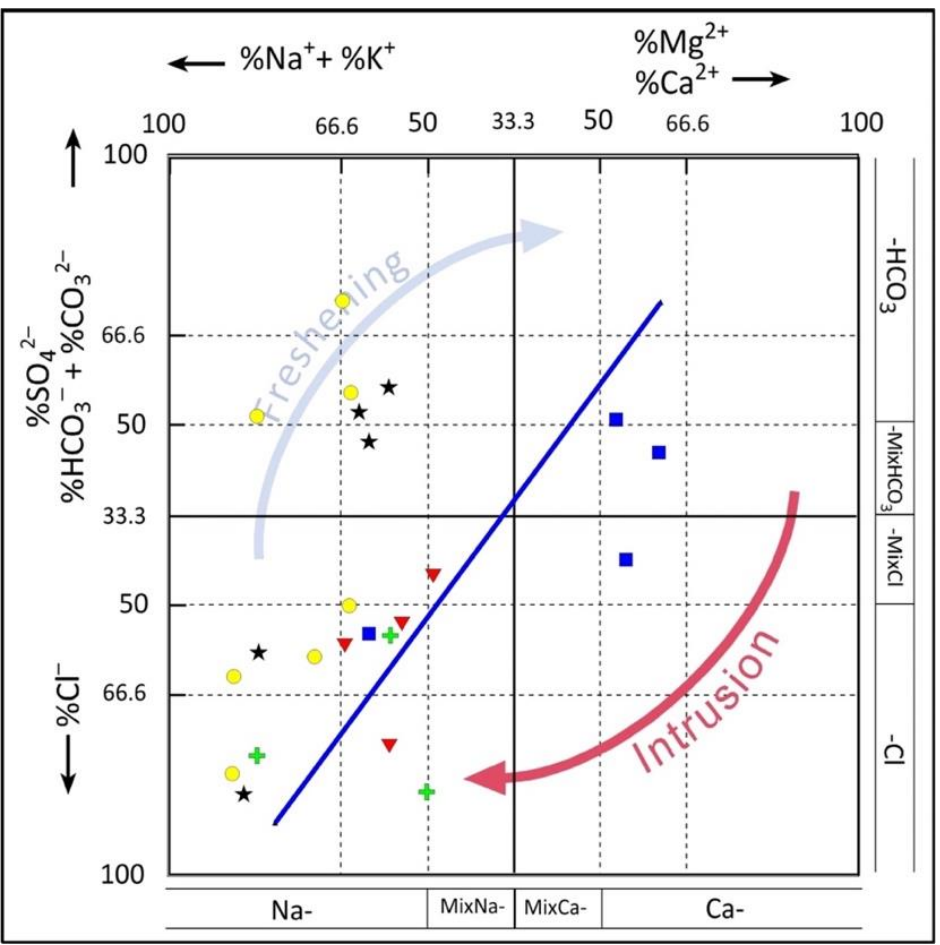

Hydrochemical facies evolution diagram for groundwater samples. Symbols as in Figure 5

\subsubsection{CATION EXCHANGE}

To investigate if ionic exchange was in partly responsible for the concentrations of the main cations, a plot of $\left(\mathrm{Ca}^{2+}+\mathrm{Mg}^{2+}\right)-\left(\mathrm{HCO}_{3}{ }^{-}\right.$ $\left.+\mathrm{SO}_{4}{ }^{2-}\right)$ vs. $\mathrm{Na}^{+}+\mathrm{K}^{+}-\mathrm{Cl}^{-}$was done, which would fit groundwaters in a line with a slope near -1 . The studied groundwater clusters fitted rather well in a line with a slope near $-1(\mathrm{y}=$ $-0.9 \mathrm{x}+0.21 ; \mathrm{R}^{2}=0.98$ ), which implies that $\mathrm{Ca}^{2+}, \mathrm{Mg}^{2+}$, and $\mathrm{Na}^{+}$interact as a result of cationic exchange processes (Fig. 8a) (e.g. FISHER; MULICAN, 1997; ZAIDI et al., 2015; ARGAMASILLA et al., 2017). Cation exchange is an important process occurring at the mineral surfaces that proceeds with a sequence during the progressive freshening, which is probably facilitated due to the high clayey fraction in the aquifers lithologies (e.g. APPELO; POSTMA, 2005; CLOUTIER et al., 2010; ARGAMASILLA et al., 2017; KIM et al., 2017; and references therein). Direct cation exchange is represented by the displacement of $\mathrm{Na}^{+}$at mineral surfaces or $\mathrm{Na}^{+}$may also come from rich- $\mathrm{Na}^{+}$fossil waters trapped in fine-grain sediments by other cations, such as $\mathrm{Ca}$ and $\mathrm{Mg}$ ions in the solution as below:

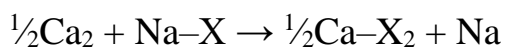


Cluster 2 samples show a scatter trend and plot near the origin suggesting a minor influence of exchange process (MCLEAN et $a l ., 2000)$. The phenomenon of ion exchange in the study area was further investigated by chloro-alkaline indices. Chloro-alkaline indices (CAI) were calculated using the following equations:

$$
\begin{gathered}
\mathrm{CAI}-1=\left[\mathrm{rCl}^{-}-\mathrm{r}\left(\mathrm{Na}^{+}+\mathrm{K}^{+}\right)\right] / \mathrm{rCl} \quad(4) \\
\mathrm{CAI}-2=\left[\mathrm{rCl}^{-}-\mathrm{r}\left(\mathrm{Na}^{+}+\mathrm{K}^{+}\right)\right] /\left[\mathrm{rSO}_{4}{ }^{2-}+\mathrm{rHCO}_{3}{ }^{-}+\mathrm{rNO}_{3}^{-}\right]
\end{gathered}
$$

Fig. $8 \mathrm{~b}$ shows that most of the samples indicate negative values for both indices, suggesting cation exchange in the system (e.g. ZAIDI et al., 2015).

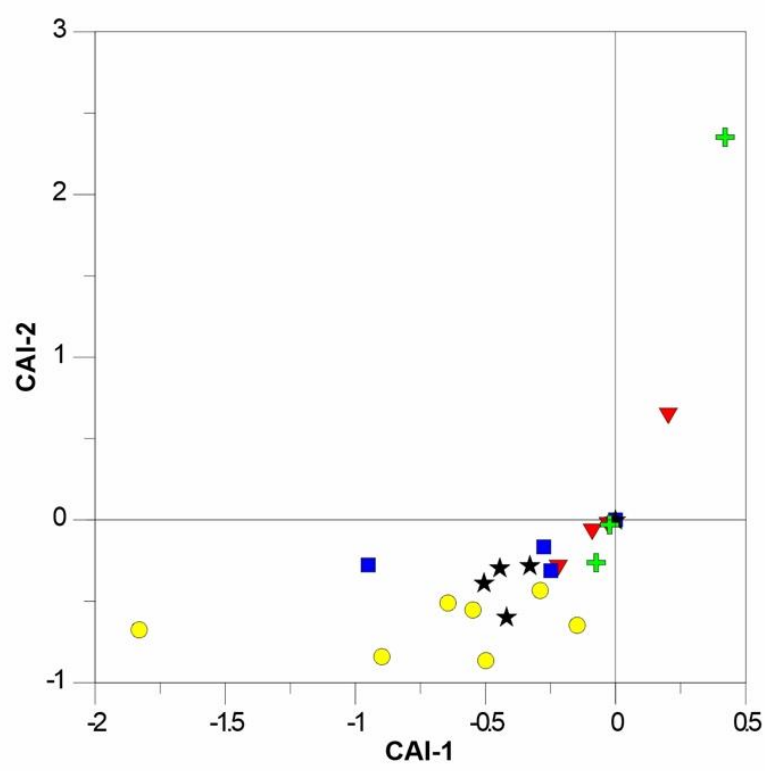

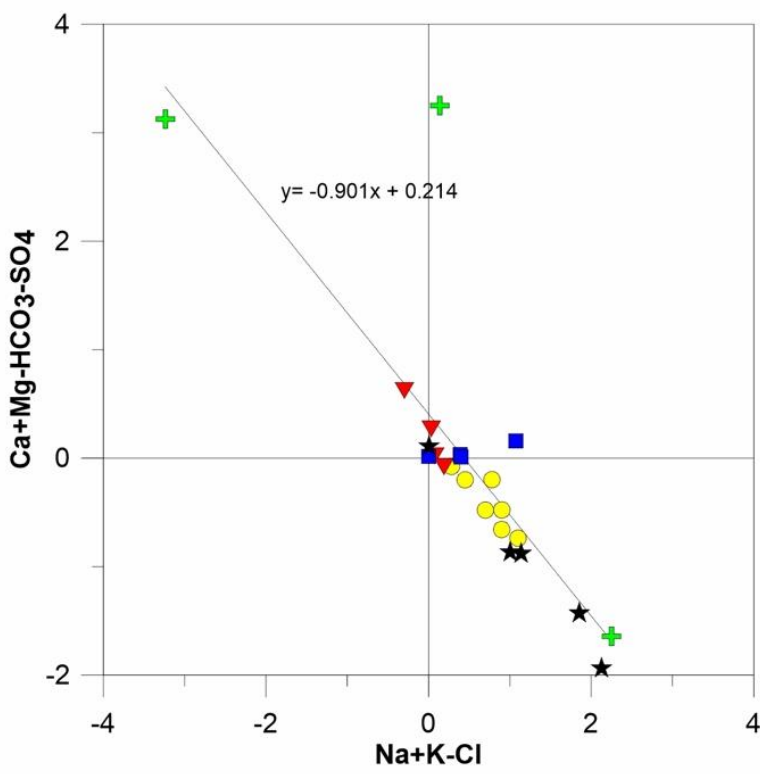

Figure 8 Bivariate diagram of $\mathbf{a} \mathrm{Ca}^{2+}+\mathrm{Mg}^{2+}-\mathrm{HCO}_{3}{ }^{-}-\mathrm{SO}_{4}{ }^{2-}$ vs. $\mathrm{Na}^{+}+\mathrm{K}^{+}-\mathrm{Cl}^{-}$, and $\mathbf{b} \mathrm{CAl}-1$ vs. CAl-2. Symbols as in Fig. 5.

\subsubsection{MECHANISMS CONTROLLING GROUNDWATER AND THEIR TYPES}

Gibbs (1970) to assess the major mechanisms acting as sources of dissolved chemical constituents in surface water (such as precipitation, rock, and evaporation dominance) propose a powerful diagram to identified between these mechanisms. As surficial waters are, at least, in part originated from groundwaters flow (e.g. JASECHKO et al., 2016); the $\mathrm{Na} /(\mathrm{Ca}+\mathrm{Na})$ vs. TDS diagram has been used by analogy to tracer groundwater processes. Although the insightful information provided, many other hydrochemical processes could imprint/superimpose a chemical signature on groundwaters due to their long-term evolution (Marandi and Shand 2018). The chemical data from the clusters were plotted in the Gibbs diagram and show that groundwater samples from them represent the influence of chemical weathering for rock-forming minerals $[\mathrm{Na} /(\mathrm{Na}+\mathrm{Ca})$ values in the range of 0.1 to 0.9 ; Fig. 9a]. The samples dominantly plot on the right side of this diagram, which further suggest travels through the flow path of precipitation from the soil and aquifer formations that triggered mainly silicate water-rock interactions (see Marandi and Shand 2018).

The Piper diagram presents the groundwater samples by cluster/sub-clusters (Fig 9b). Cluster 1a presents $\mathrm{Na}^{+}-\mathrm{HCO}_{3}^{-}$to $\mathrm{Na}^{+}-\mathrm{Cl}^{-}$water type and cluster $1 \mathrm{~b}$ has a $\mathrm{Na}^{+}-\mathrm{Cl}^{-}$type with the lowest TDS values. Cluster 2 has a well-defined $\mathrm{Ca}^{2+}-\mathrm{SO}_{4}{ }^{2-}\left(\mathrm{Cl}^{-}\right)$type. Clusters $3 \mathrm{a}$ and $3 \mathrm{~b}$ have $\mathrm{Na}^{+}-\mathrm{Cl}^{-}$facies presenting the highest TDS values that occur in southwestern of Recife. 

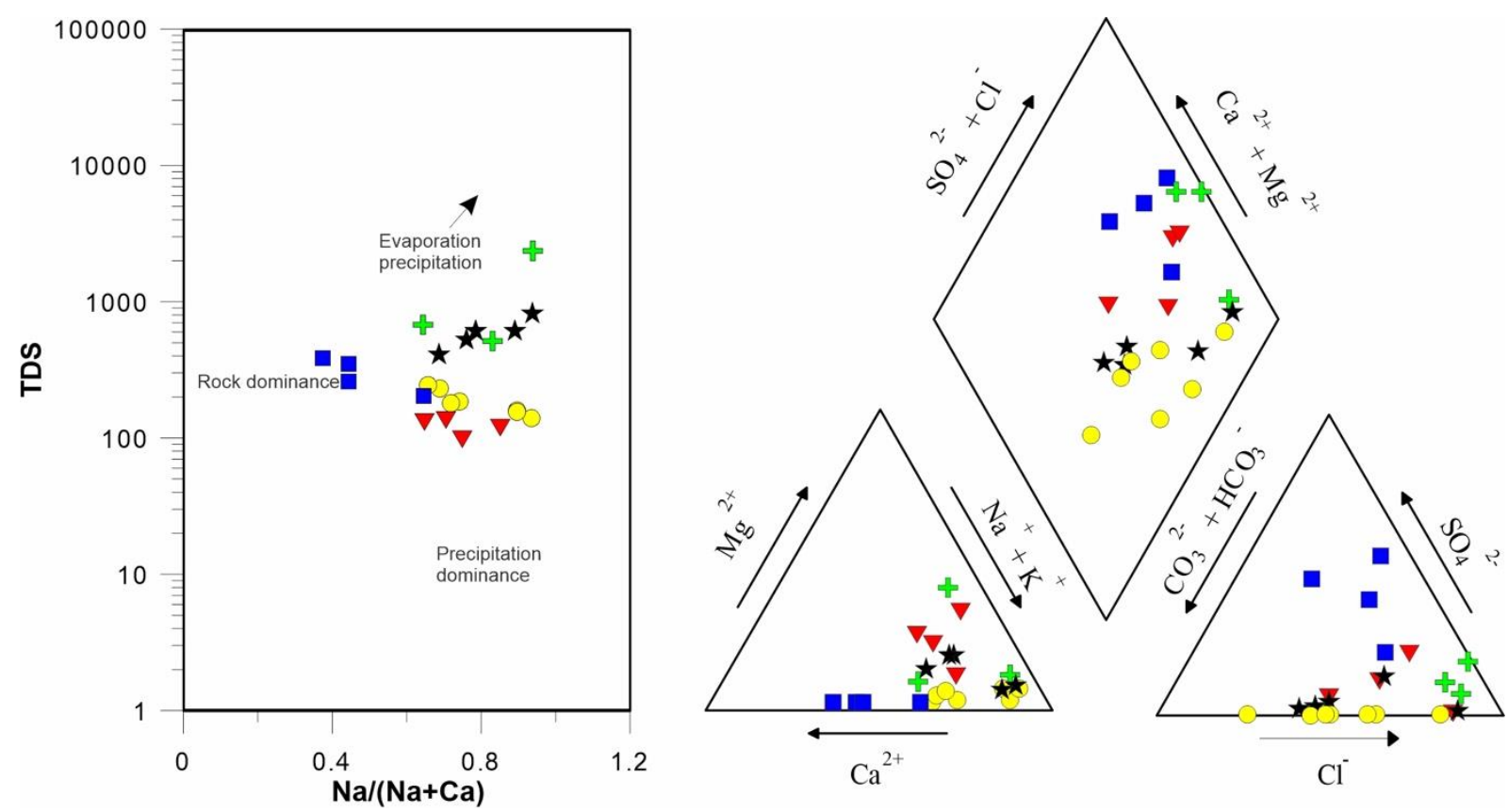
b) Piper diagram of groundwater samples labeled according to their groundwater clusters. Symbols as in Fig. 5 .

\subsubsection{SILICATE WEATHERING}

Silicate is one of the main lithologies undergoing high chemical weathering, which contributes to the dissolved load in waters (e.g. GAILLARDET et al., 1997). As such, silicate weathering constitutes a key geochemical process controlling water chemistry. The ratios between $\mathrm{Na}^{+}$, and $\mathrm{Cl}^{-}$and total cations $\left(\mathrm{T}_{\mathrm{Z}}^{+}\right)$ were done to estimate weather silicate weathering plays a role. $\mathrm{Na}^{+} / \mathrm{Cl}^{-}$ratios of all clusters, except $3 b$, plot above the equiline $1: 1$ (Fig. 10a). This higher ratio suggests an excess of $\mathrm{Na}+$ released from silicate weathering (STALLARD; EDMOND 1983; MEYBECK 1987; CARTWRIGHT; WEAVER 2005). On the plot of $\mathrm{Na}^{+}$and total cations $\left(\mathrm{TZ}^{+}\right)$, groundwater samples from the sub-cluster 1a and $3 \mathrm{a}$ plot above the 1:2 line, indicating an abundance of silicate weathering. Similarly, sub-cluster $1 \mathrm{~b}, 2$, and $3 \mathrm{~b}$ fall between $1: 3$ and 1:2 indicating some silicate weathering (Fig. 10b). $\quad \mathrm{Ca}^{2+} / \mathrm{Cl}^{-}, \quad \mathrm{K}+/ \mathrm{Cl}^{-}, \quad \mathrm{Mg}^{2+} / \mathrm{Cl}^{-}, \quad$ and $\mathrm{HCO}_{3}{ }^{-} / \mathrm{Cl}^{-}$(not shown) present ratios higher than the marine one suggesting that weathering of alumino-silicate minerals (feldspars, micas, and amphiboles) contribute to the high concentration of these ions.
In scatter plots of $\left(\mathrm{Ca}^{2+}+\mathrm{Mg}^{2+}\right)$ vs. $\left(\mathrm{HCO}_{3}{ }^{-}\right.$ $+\mathrm{SO}_{4^{2-}}$ ), sub-clusters $1 \mathrm{~b}$ and $3 \mathrm{~b}$ fall above the equiline indicating an excess of $\mathrm{Ca}^{2+}+\mathrm{Mg}^{2+}$ as well as a potential for the release of these elements by silicate weathering (Fig. 10c). Otherwise, sub-clusters 1a and 3a groundwater samples plotted below the 1:1 line, indicating that the excess of $\mathrm{HCO}_{3}^{-}+\mathrm{SO}_{4}{ }^{-2}$ must be balanced by $\mathrm{Na}^{+}$and suggests silicate weathering of $\mathrm{Na}^{+}+\mathrm{K}^{+}$or ion exchange process taking place with $\mathrm{Ca}^{2+}+\mathrm{Mg}^{2+}$ (e.g. Maurya et al., 2019). Cluster 2 samples fall along the equiline suggesting that dolomite, calcite, or gypsum dissolution process play a role (e.g. CERLING et al., 1989; FISHER; MULLICAN 1997; LADESMA-RUIZ et al., 2015; ZAIDI et al., 2015). The plot of $\mathrm{Ca}^{2+}$ versus $\mathrm{SO}_{4}{ }^{2-}$ and $\mathrm{HCO}_{3}^{-}$(not shown) suggests that minor carbonates and sulfates dissolution may contribute to groundwater from cluster 2 ; since dolomite and calcite normally plot on an equivalent ratio between $1: 4$ and $1: 2$, between dissolved $\mathrm{Ca}^{2+}$ and $\mathrm{HCO}_{3}{ }^{-}$, and plot in the equiline between $\mathrm{Ca}^{2+}$ and $\mathrm{SO}_{4}{ }^{2-}$. Sulfate dissolution is probably more influential to this cluster 2 as further evidenced bellow. 

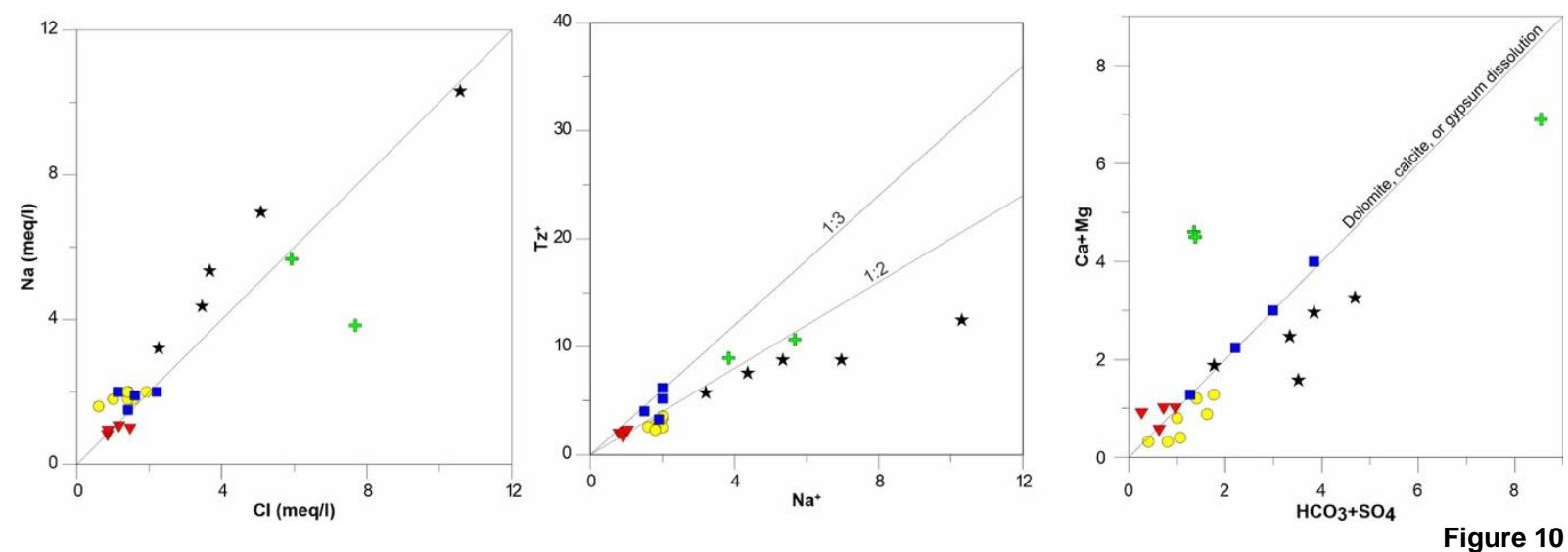

Binary plots in milliequivalent for: a $\mathrm{Na} v s . \mathrm{Cl}, \mathbf{b} \mathrm{Na}^{+}$vs. total cations $\left(\mathrm{TZ}^{+}\right)$, and $\mathbf{c} \mathrm{Ca}^{2+}+\mathrm{Mg}^{2+}$ vs. $\mathrm{HCO}_{3}{ }^{-}+\mathrm{SO}_{4}{ }^{2-}$ from the groundwater separated by cluster/sub-clusters. Symbols as in Fig. 5.

\subsubsection{SATURATION INDICES}

Saturation indices (SI) are important to determine the reactivity of minerals in groundwater. A positive value of SI for a particular mineral indicates oversaturation and thus precipitation could occur otherwise a negative value means undersaturation and mineral dissolution is possible to take place. The groundwater samples from all cluster/subclusters have halite saturation index very low ( $\leq$ -4.75 ), which indicates that the dissolution of halite, if any occurs in the aquifers, is of negligible importance (Fig. 11). Gypsum and anhydrite saturation indices for all samples, -1.51 and -1.75 , respectively, indicate

\subsubsection{GROUNDWATER FLOW PATH}

In a geographical sense, the three groundwater clusters are well-separated as we can see in Fig. 5, suggesting that the samples that belong to the same cluster generally have similar chemical properties due to similar underlying processes and/or groundwater flow paths. Fig. 5 shows that the hydrochemical evolution occurs from cluster $1(\mathrm{C} 1) \rightarrow$ cluster 2 (C2) $\rightarrow$ cluster 3 (C3) in $\mathrm{W}-\mathrm{E}$ direction, which agrees with poorly known general groundwater flow path in the study area (Fig. 1). At the West, the higher topographic areas favored recharge, where igneous basement rocks outcrops and constitutes one of the recharge pools of the system. The groundwater chemistry in the area varies from $\mathrm{Na}^{+}-\mathrm{HCO}_{3}{ }^{-}$to $\mathrm{Na}^{+}-\mathrm{Cl}^{-}$- water type (C1) with lower TDS undersaturation concerning these minerals arguing against sulfate precipitation with the higher values found in cluster 2. Apart from seawater intrusion, gypsum and anhydrite dissolution might contribute $\mathrm{SO}_{4}{ }^{2-}$ for cluster 2 that have the highest SI. For calcite, dolomite, and aragonite the SI indicates that most of the samples are undersaturated, except for few samples from sub-clusters $3 \mathrm{a}$ and $3 \mathrm{~b}$ that are near equilibrium. Undersaturation of almost all minerals indicates that groundwater had not enough residence time to reach up to equilibrium and that dissolution is probably taking place.

$(\sim 160 \mathrm{mg} / \mathrm{L})$ in the West to $\mathrm{Ca}^{2+}-\mathrm{SO}_{4}{ }^{2-}\left(\mathrm{Cl}^{-}\right)$ water type (C2) with higher TDS $(\sim 300 \mathrm{mg} / \mathrm{L})$ than $\mathrm{C} 1$ to $\mathrm{Na}^{+}-\mathrm{Cl}^{-}$water type (C3) with highest TDS $(\sim 700 \mathrm{mg} / \mathrm{L})$ in the East. The infiltration water that progress is compatible with freshening (decreasing $\mathrm{Cl}^{-}$from $\mathrm{C} 3$ to $\mathrm{C} 1$; Table 3) and ion exchange processes with dissolution of silicates and minor sulfate/carbonate. Silicate dissolution becoming a dominant process toward transitional to discharge areas during the water-rock evolution of groundwater. Summarizing, the concentration of TDS increase from the West to the East, and the groundwater chemical type changes from $\mathrm{Na}^{+}-\mathrm{Cl}^{-}-\mathrm{HCO}_{3}{ }^{-}$to $\mathrm{Na}^{+}-\mathrm{Cl}^{-}$type, which indicates hydrogeochemical evolution along the groundwater flow path. 

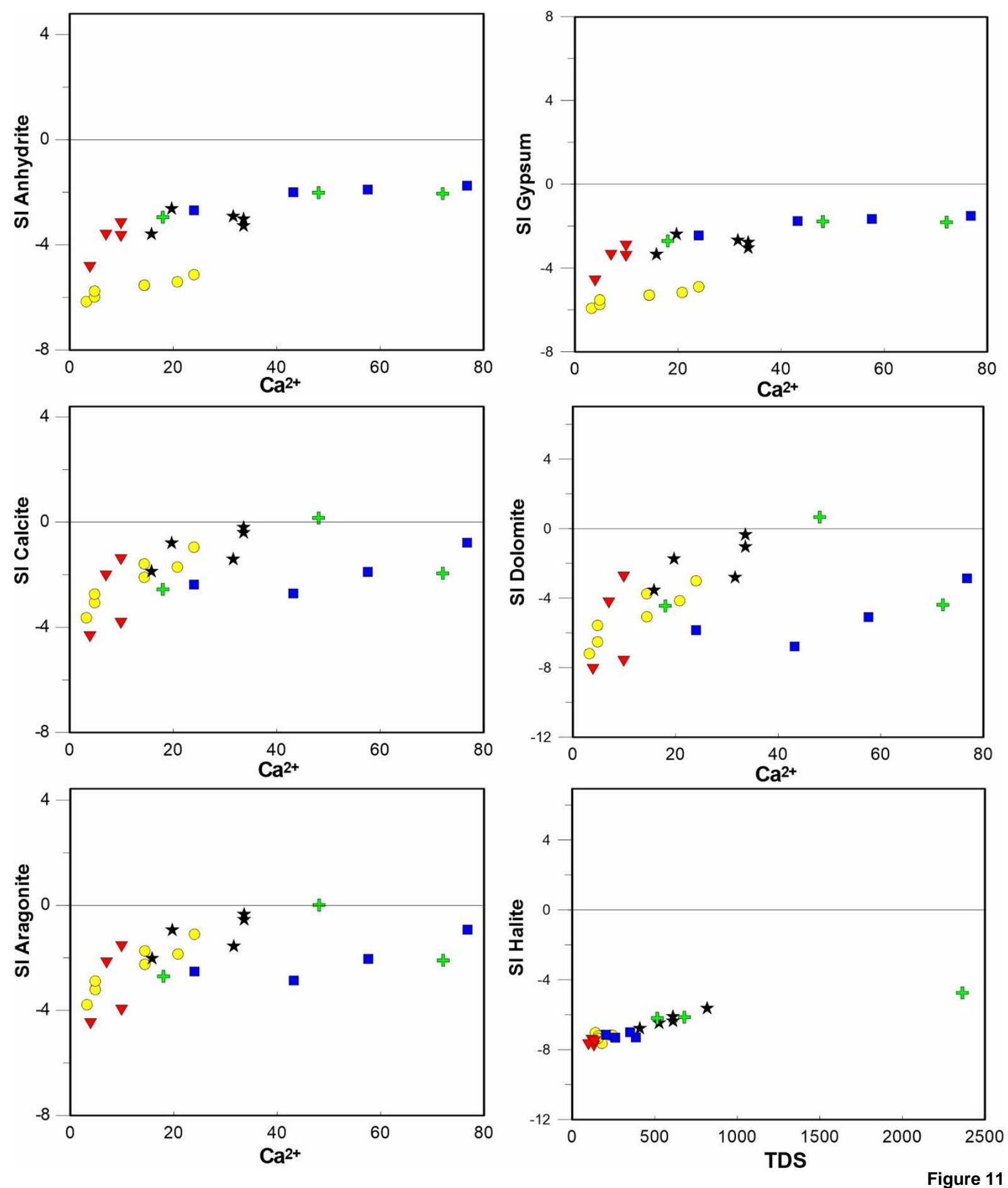

Saturation indices of groundwater for the selected mineral phases. Symbols as in Fig. 5.

\section{CONCLUSIONS}

In this study, a combined hydrochemical conventional approach along with multivariate statistical analyses and GIS mapping is used to understand the mineralization quality status and geochemical processes occurring in the unconfined marine to alluvial Boa Viagem coastal aquifer. Hydrochemical results show that do not only geogenic processes affected the Recife municipality, but anthropogenic inputs were recognized. $\sim 30 \%$ of the analyzed parameters exceed the WHO threshold for drinking water quality. Conversely, relatively high $\mathrm{NO}_{3}{ }^{-}$concentration occurs in the study area, but only one sample showed the presence of nitrate above $50 \mathrm{mg} / \mathrm{L}$. Q-mode HCA allowed the recognition of three distinct clusters and five sub-clusters (1a, 1b, 2, 3a, 3b). Cluster 1 presents a diluted $\mathrm{Na}^{+}-\mathrm{HCO}_{3}{ }^{-}$to $\mathrm{Na}^{+}-\mathrm{Cl}^{-}$type (avg. TDS $=162 \mathrm{mg} / \mathrm{L}$; next to precipitation dominance), cluster 2 shows $\mathrm{Ca}^{2+}-\mathrm{SO}_{4}{ }^{2-}$ type 
(avg. TDS $=300 \mathrm{mg} / \mathrm{L}$ ), and cluster 3 presents a mineralized $\mathrm{Na}^{+}-\mathrm{Cl}^{-}$type (avg. TDS $=680$ $\mathrm{mg} / \mathrm{L}$ ). Three principal components (PC1-PC3) explained $80.40 \%$ of the variance of the original data set. PC1 and PC2 (39.85\% and $21.56 \%$ of the variance, respectively) assigned to 'geogenic', and PC3 to 'anthropogenic and geogenic' processes. PC1 suggests freshening and direct cation exchange processes when flushing of inherited saline waters from seawater intrusion of the latest marine transgression takes place. PC2 indicates the chemical interaction between groundwater and soil and rocks. PC3 is probably related to leakage from a deficient sewage/drainage network and from many septic tanks since Recife is a densely built area with deficient public sewage system, which requires investments and improvements in basic sanitation to avoid further contamination. Several conventional diagrams (Stiff, Gibbs, Piper, HFE-D), scatter plots between the ions, and saturation indices also evidence about the processes such as freshening, cation-exchange, silicate and sulfate weathering which reinforces the information highlighted from statistical methods. Our study emphasizes that the

\section{ACKNOWLEDGMENTS}

This study was carried out within the water sustainability project under loan agreement $\mathrm{N}^{\circ}$ 7778-BR through the International Bank for Reconstruction and Development (IBRD). We thank the director Maria Lorenzza Leite from the Water and Climate Agency of Pernambuco (APAC) for her permission to publish this manuscript. However, the opinions expressed

\section{REFERENCES}

ALLAN J.A. Virtual Water: A Strategic Resource. Global Solutions to Regional Deficits. Ground Water, 36:545-546, 1998.

https://doi.org/10.1111/j.1745-6584.1998.tb028 25.x

ALMEIDA J.B.; BARROS J.F.; MESQUITA B.A.; SILVA C.M.S.V.; FILHO J.M.; FRISCHKORN H.; SANTIAGO M.M.F. Cluster analysis and geochemical processes for the characterization of the aquifer system in Maracanã/São Luis/MA. Brazilian Journal of Water Resources, 21:832-840, 2016 http://doi.org/10.1590/23180331.011615182

APHA, AWWA, WEF, 2012. Standard Methods for examination of water and wastewater. 22nd ed. Washington: American Public Health Association, $1360 \mathrm{pp}$. combination of multivariate statistical analyses (hierarchical cluster and principal component analyses) with classical geochemical methods could be used to understand long-term hydrogeochemical processes, which is necessary recognize to effective management actions. In addition, this regional analysis is relevant for the development management policies. Land use planning policies must contemplate the maintenance of natural recharge areas as fundamental for the good management of water resources (including also surface water), either through municipal or regional plans that transpose national action guidelines. It should also be noted that overexploitation of aquifers, particularly in coastal regions, will intensify the problem of advancing saltwater intrusion, affecting underground reserves. Projects such as those that have been developed by water and sanitation regulators in the metropolitan region of Recife and the state of Pernambuco are serving as a basis for, in addition to increasing knowledge about water resources, establishing and implementing criteria for management and protection of groundwater.

here are solely our responsibility and do not necessarily reflect those of the APAC authorities. Dr. M. Oliveira is thanked for proofreading and review the text. We are grateful to Prof. Jorge de Lena, Editor-in-Chief, for his editorial work, and to one anonymous reviewer for comments.

APPELO C.A.J.; POSTMA D. Geochemistry, Groundwater and Pollution. A.A. Balkema Publishers. Leiden The Netherlands. 2nd Ed. 634 pp. 2005

ARGAMASILLA M.; BARBERÁ J.A.; ANDREO B. Factors controlling groundwater salinization and hydrogeochemical processes in coastal aquifers from southern Spain. Science of the Total Environment, 580:50-68, 2017 https://doi.org/10.1016/j.scitotenv.2016.11.173

BIANCHINI G. ; PENNISI M. ; CIONI R. ; MUTI A. ; CERBAI N. ; KLOPPMANN W. Hydrochemistry of the high-boron groundwaters of the Cornia aquifer (Tuscany, Italy). Geothermics, 34:297-319, 2005

https://doi.org/10.1016/j.geothermics.2005.04.002 
BORETTI A.; ROSA L. Reassessing the projections of the World Water Development Report. Clean Water, 2:15, 2019 https://doi.org/10.1038/s41545-019-0039-9

BRAZILIAN NAVY, Tide Tables for Brazilian Ports. Available at https://www.marinha. mil.br/chm/tabuas-de-mare 2020

CARTWRIGHT I.; WEAVER T.R. Hydrogeochemistry of the Goulburn Valley region of the Murray Basin, Australia: implications for flow paths and resource vulnerability. Hydrogeology Journal, $\quad 13: 752-770, \quad 2005$ https://doi.org/10.1007/s10040-003-0318-9

CARTWRIGHT I.; WEAVER T.; Petrides B. Controls on ${ }^{87} \mathrm{Sr} /{ }^{86} \mathrm{Sr}$ ratios of groundwater in silicate dominated aquifers: SE Murray Basin, Australia. Chemical Geology, 246:107-123, 2008 https://doi.org/10.1016/j.chemgeo.2007.09.006

CERLING T.E.; PEDERSON B.L.; VON DAMN K.L. Sodium-calcium ion exchange in the weathering of shales: Implications for global weathering budgets. Geology, 17:552-554, 1989 https://doi.org/10.1130/00917613(1989)017<0552:SCIEIT >2.3.CO;2

CLOUTIER V.; LEFEBVRE R.; SAVARD M.M.; THERRIEN R. Desalination of a sedimentary rock aquifer system invaded by Pleistocene Champlain Sea water and processes controlling groundwater geochemistry. Environmental Earth Sciences, 59:977-994, 2010 https://doi.org/10.1007/s12665-009-0091-8

CLOUTIER V.; LEFEBVRE R.; THERRIEN R.; SAVARD M.M. Multivariate statistical analysis of geochemical data as indicative of the hydrogeochemical evolution of groundwater in a sedimentary rock aquifer system. Journal of Hydrology, 353:294- 313, 2008

https://doi.org/10.1016/j.jhydrol.2008.02.015

COSTA W.D.; SANTOS A.C.; COSTA FILHO W.D. O Controle Estrutural na Formação dos Aquíferos na Planície do Recife. In: $8^{\circ}$ Congresso Brasileiro de Águas Subterrâneas. 1994 Recife, PE. Anais... 38-43. Available at https://aguassubterraneas.abas.org/asubterraneas /article/view/24353

COSTA W.D.; MANOEL FILHO J.; SANTOS A.C.; MONTEIRO A.B.; SOUZA F.A.S.; LOPES A.V.G.; SANTOS A.J.C. Estudo hidrogeológico da região metropolitana do Recife. - Projeto HIDROREC I. Convênio IDRC. UFPE/FADE. Recife 1998. 2V

COSTA W.D.; COSTA H.F.; FERREIRA C.A.; MORAIS J.F.S.; VILLA VERDE E.R.; COSTA L.B.; COSTA FILHO W.D. 2002. Estudo hidrogeológico de Recife, Olinda, Camaragibe, Jaboatão dos Guararapes. Projeto HIDROREC II. 2. SRH/PE. Recife 2002. $2 \mathrm{~V}$

CRUZ-FUENTES T.; CABRERA M.C.; HEREDIA J.; CUSTODIO E. Groundwater salinity and hydrochemical processes in the volcanosedimentary aquifer of La Aldea, Gran Canaria,
Canary Islands, Spain. Science of the Total Environment, 484:154-166, 2014 https://doi.org/10.1016/j.scitotenv.2014.03.041

CUSTODIO E. Coastal aquifers of Europe: an overview. Hydrogeology Journal, 18:269-280, 2010 https://doi.org/10.1007/s10040-009-04961

DOMINGUEZ J.M.A.; BITTENCOURT A.C.S.P.; LEÃO Z.M.A.N.; AZEVEDO A.E.G. Geologia do Quaternário costeiro do Estado de Pernambuco. Revista Brasileira de Geociências, 20:208-215, 1990 https://doi.org/10.25249/0375-7536.1990208215

EPA Method 6010C (SW-846): Inductively Coupled Plasma-Atomic Emission Spectrometry, Revision 3:1-34, 2007

FISHER R.S.; MULLICAN W.F. Hydrochemical evolution of sodium-sulfate and sodium-chloride groundwater beneath the Northern Chihuahuan Desert, Trans-Pecos, Texas, USA. Hydrogeology Journal, 5:4-16, 1997 https://doi.org/10.1007/s100400050102

FREEZE R.A.; CHERRY J.A. Groundwater. Prentice-Hall Inc., Englewood Cliffs, New Jersey 07632, 604 pp, 1997

GAILLARDET J.; DUPRE B.; ALLEGRE C.J.; NEGREL P. Chemical and physical denudation in the Amazon River Basin. Chemical Geology, 142:141-173, 1997 https://doi.org/10.1016/S0009-2541(97)00074-0

GIBBS R.J. Mechanisms Controlling World Water Chemistry. Science, 70:1088-1090, 1970 https://doi.org/10.1126/science.170.3962.1088

GIMÉNEZ-FORCADA E. Dynamic of seawater interface using hydrochemical facies evolution diagram. Ground Water, 48:212-216, 2010 https://doi.org/10.1111/j.17456584.2009.00649.x

GIMÉNEZ-FORCADA E. Space/time development of seawater intrusion, a study casein Vinaroz coastal plain (Eastern Spain) using HFEdiagram, and spatial distribution of hydrochemical facies. Journal of Hydrology, 517:617-627, 2014 https://doi.org/10.1016/j.jhydrol.2014.05.056.

GÜLER C.; KURT M.A.; ALPASLAN M.; AKBULUT C. Assessment of the impact of anthropogenic activities on the groundwater hydrology and chemistry in Tarsus coastal plain (Mersin, SE Turkey) using fuzzy clustering, multivariate statistics and GIS techniques. Journal of Hydrology, 414-415:435-451, 2012 https://doi.org/10.1016/j.jhydrol.2011.11.021

GÜLER C.; THYNE G.D.. Hydrologic and geologic factors controlling surface and groundwater chemistry in Indian Wells-Owens valley area, southeastern California, USA. Journal of Hydrology, 285:177-198, 2004 https://doi.org/10.1016/j.jhydrol.2003.08.019

GÜLER C.; THYNE G.D.; MCCRAY J.E.; TURNER A.K. Evaluation of graphical and multivariate statistical methods for classification 
of water chemistry data. Hydrogeology Journal, 10:455-474, 2002 https://doi.org/10.1007/s10040-002-0196-6

HAN D.; KOHFAHL C.; SONG X.; XIAO G.; YANG J. Geochemical and isotopic evidence for palaeo-seawater intrusion into the south coast aquifer of Laizhou Bay, China. Applied Geochemistry, 26:863-883, 2011 https://doi.org/10.1016/j.apgeochem.2011.02.007

HELENA B.; PARDO B.; VEGA M.; BARRADO E.; FERNANDEZ J.M.; FERNANDEZ L. Temporal evolution of groundwater composition in an alluvial aquifer (Pisuerga River, Spain) by principal component analysis. Water Research, 34:807-816, 2000 https://doi.org/10.1016/S0043-1354(99)00225-0 JASECHKO S.; BIRKS S.J.; GLEESON T.; WADA Y.; FAWCETT P.J.; SHARP Z.D.; MCDONNELL J.J.; WELKER J.M. The pronounced seasonality of global groundwater recharge, Water Resources Research, 50:88458867,2014 https://doi.org/10.1002/2014WR015809

JASECHKO S.; KIRCHNER J.W.; WELKER J.M.; MCDONNELL J.J. Substantial proportion of global streamflow less than three months old. Nature Geoscience, 9:126-129, 2016 https://doi.org/10.1038/ngeo2636

JOLLIFFE I.T.; CADIMA G. Principal component analysis: a review and recent developments. Philosophical Transactions of the Royal Society A, 374:20150202, 2016 http://doi.org/10.1098/rsta.2015.0202

KAZAKIS N.; MATTAS C.; PAVLOU A.; PATRIKAKI O.; VOUDOURIS K. Multivariate statistical analysis for the assessment of groundwater quality under different hydrogeological regimes. Environmental Earth Sciences, 76:349, 2017 https://doi.org/10.1007/s12665-017-6665-y

KIM J.-H.; KIM K.-H.; THAO N.T.; BATSAIKHAN B.; YUN S.-T. Hydrochemical assessment of freshening saline groundwater using multiple end-members mixing modeling: A study of Red River delta aquifer, Vietnam. Journal of Hydrology, 549:703-714, 2017 https://doi.org/10.1016/j.jhydrol.2017.04.040

KRONEMBERGER D. Análise dos impactos na saúde e no sistema único de saúde decorrentes de agravos relacionados a um esgotamento sanitário inadequado dos 100 maiores municípios brasileiros no Período 2008-2011. Trata Brasil, relatório final $74 \mathrm{pp}, 2013$

LADESMA-RUIZ R.; PASTÉN-ZAPATA E.; PARRA R.; HARTER T.; MAHLKNECHT J. Investigation of the geochemical evolution of groundwater under agricultural land: A case study in northeastern Mexico. Journal of Hydrology, 521:410-423, 2015 https://doi.org/10.1016/j.jhydrol.2014.12.026

LARSEN F.; TRAN L.V.; VAN HOANG H.; TRAN L.T.; CHRISTIANSEN A.V.; PHAM N.Q. Groundwater salinity influenced by Holocene seawater trapped in incised valleys in the Red River delta plain. Nature Geoscience, 10: 376381, 2017 https://doi.org/10.1038/ngeo2938

LE T.T.V.; LERTSIRIVORAKUL R.; BUI T.V.; SCHULMEISTER M.K. An application of HFE$\mathrm{D}$ for evaluating seawater intrusion in coastal aquifers of Southern Vietnam. Groundwater 58(6):1012-1022 2020 https://doi.org/10.1111/gwat.13022

LI X.; WU H.; QIAN H.; GAO Y. Groundwater chemistry regulated by hydrochemical processes and geological structures: a case study in Tongchuan, China. Water, 10:1-16, 2018 https://doi.org/10.3390/w10030338

MARANDI A.; SHAND P. Groundwater chemistry and the Gibbs Diagram. Applied Geochemistry, 97:209-212, 2018

https://doi.org/10.1016/j.apgeochem.2018.07.009

MAURYA P.; KUMARI R.; MUKHERJEE. Hydrochemistry in integration with stable isotopes $(\delta 18 \mathrm{O}$ and $\delta \mathrm{D})$ to assess seawater intrusion in coastal aquifers of Kachchh district, Gujarat, India. Journal of Geochemical Exploration 196:42-56, 2019 https://doi.org/10.1016/j.gexplo.2018.09.013

MCLEAN W.; JANKOWSKII J.; LAVITT N. Groundwater quality and sustainability in an alluvial aquifer, Australia, in: Sililo, O., et al. (Eds.), Groundwater, past achievements and future challenges. AA Balkema, Rotterdam, pp. 567-573, 2000

MENCIÓ A.; MAS-PLA J. Assessment by multivariate analysis of groundwater-surface water interactions in urbanized Mediterranean streams. Journal of Hydrology, 252:255-266, 2008 https://doi.org/10.1016/j.jhydrol.2008.01.014

MEYBECK M. Global chemistry weathering of surficial rocks estimated from river dissolved loads. American Journal of Sciences, 287:401428, 1987 https://doi.org/10.2475/ajs.287.5.401

MIRZAVAND M.; GHASEMIEH H.; SADATINEJAD S.J.; BAGHERI R. An overview on source, mechanism and investigation approaches in groundwater salinization studies. International Journal of Environmental Science and Technology, 17:2463-2476, 2020 https://doi.org/10.1007/s13762-020-02647-7

MONJEREZI M.; VOGT R.D.; AAGAARD P.; SAKA J.D.K. Hydro-geochemical processes in an area with saline groundwater in lower Shire River valley, Malawi: An integrated application of hierarchical cluster and principal component analyses. Applied Geochemistry, 26:13991413 , 2011 https://doi.org/10.1016/j.apgeochem.2011.05.01 3

MONTETY V.; RADAKOVITCH O.; VALLETCOULOMB C.; BLAVOUX B.; HERMITTE D.; VALLES V. Origin of groundwater salinity and hydrogeochemical processes in a confined coastal aquifer: Case of the Rhône delta 
(Southern France). Applied Geochemistry, 23:2337-2349, 2008. https://doi.org/10.1016/ j.apgeochem.2008.03.011

MOYA C.E.; RAIBER M.; TAULIS M.; COX M.E. Hydrochemical evolution and groundwater flow processes in the Galilee and Eromanga basins, Great Artesian Basin, Australia: A multivariate statistical approach. Science of The Total Environment, 508:411-426, 2015 https://doi.org/10.1016/j.scitotenv.2014.11.09

MUKHERJEE I.; SINGH U.K. Fluoride abundance and their release mechanisms in groundwater along with associated human health risks in a geologically heterogeneous semiarid region of east India. Microchemical Journal, $152: 104304,2020$

https://doi.org/10.1016/j.microc.2019.104304

NOSHADI M.; GHAFOURIAN A. Groundwater quality analysis using multivariate statistical techniques (case study: Fars province, Iran). Environmental Monitoring and Assessment, 188:419, 2016 https://doi.org/10.1007/s10661016-5412-2

PAIVA A.L.R. 2004. Modelagem computacional e análise da salinização dos aquíferos na área central de Recife. Master dissertation. Federal University of Pernambuco, Recife, Brazil, 147 pp, (in Portuguese with English abstract).

PAIVA A.L.R.; MONTENEGRO S.M.G.L.; CABRAL J.J.S.P.; COUTINHO A.P.; SILVA S.C. Evolução da mancha urbana do Recife e seus efeitos na recarga do aquífero Boa Viagem. In: XXI Simpósio Brasileiro de Recursos Hídricos. Brasília, Anais... DF, 1-7, 2015

PARKHURST D.L.; APPELO C.A.J. Description of input and examples for PHREEQC version 3: a computer program for speciation, batchreaction, one-dimensional transport, and inverse geochemical calculations. U.S. Geological Survey, Techniques and Methods, 6A43, 497 pp, 2013 https://doi.org/10.3133/tm6A43

PRUSTY P.; FAROOQ S.H.; SWAIN D.; CHANDRASEKHARAM D. Association of geomorphic features with groundwater quality and freshwater availability in coastal regions. International Journal of Environmental Science and Technology, 17:3313-3328, 2020 https://doi.org/10.1007/s13762-020-02706-Z

RAKOTONDRABE F.; NGOUPAYOU J.R.N.; MFONKA Z.; RASOLOMANANA E.H.; ABOLO A.J.N.; AKO A.A. Water quality assessment in the Bétaré-Oya gold mining area (East-Cameroon): Multivariate Statistical Analysis approach. Science of The Total Environment, 610-611:831-844, 2018 https://doi.org/10.1016/j.scitotenv.2017.08.080

SILVA T.R.; LEITÃO T.E.; LIMA M.M.C.; MARTINS T.N.; OLIVEIRA M.M.; ALBUQUERQUE M.S.C.; COSTA W.D., Hydrogeochemistry and isotope compositions of multi-layered aquifer systems in the Recife Metropolitan Region, Pernambuco (NE Brazil):
An integrated approach using multivariate statistical analyses. Journal of South American Earth Sciences, 109:103323, 2021 https://doi.org/10.1016/j.jsames.2021.103323.

SINGH K.P. MALIK A.; MOHAN D.; SINHA S. Multivariate statistical techniques for the evaluation of spatial and temporal variations in water quality of Gomti River (India) - a case study. Water Research, 38:3980-3992, 2004 https://doi.org/10.1016/j.watres.2004.06.011

SINGH K.C.; KUMAR A.; SHASHTRI S.; KUMAR A.; KUMAR P.; MALLICK J. Multivariate statistical analysis and geochemical modeling for geochemical assessment of groundwater of Delhi, India. Journal of Geochemical Exploration, 175:59-71, 2017 https://doi.org/10.1016/j.gexplo.2017.01.001

STALLARD R.F.; EDMOND J.M. Geochemistry of Amazon: 2. The influence of geology and weathering environment on the dissolved load. Journal of Geophysical Research, 88:96719688, 1983 https://doi.org/10.1029/JC088iC14p09671.

SUGUIO K.; BARRETO A.M.F.; OLIVEIRA P.E.; BEZERRA F.H.R.; VILELA M.C.S.H. Indicators of Holocene sea level changes along the coast of the states of Pernambuco and Paraíba, Brazil. Geologia USP. Série Científica, 13:141-152, 2013 https://doi.org/10.5327/Z1519 $-874 X 201300040008$

THYNE G.; GÜLER C.; POETER E. Sequential Analysis of Hydrochemical Data for Watershed Characterization. Groundwater, 42:711-723, 2004 https://doi.org/10.1111/j.1745-6584.2004. tb02725.x

UNESCO, 2015. The United Nations World Water Development Report 2015: Water for a sustainable world. Available at http://www.unesco.org/new/fileadmin/MULTI MEDIA/HQ/SC/images/WWDR2015Facts_Fig ures_ENG_web.pdf

VENGOSH A.; ROSENTHAL E. Saline groundwater in Israel: its bearing on the water crisis in the country. Journal of Hydrology, 156:389 430, 1994 https://doi.org/10.1016/00221694(94)90087-6

VENTURELLI G.; BOSCHETT T.; DUCHI V. Nacarbonate waters of extreme composition: Possible origin and evolution. Geochemical Journal, 37:351-366, 2003 https://doi.org/10.2343/geochemj.37.351

VISEU M.T.; RODRIGUES R.; OLIVEIRA M.M. Caracterização pluviométrica da Região Metropolitana do Recife. Laboratório Nacional de Engenharia Civil, relatório 45/2016, 76pp, 2016

WHO, 2011. Guidelines for Drinking-water Quality Recommendations. fourth edition. 518 pp.

WANG J.; LIANG X.; LIU Y.; JIN M.; KNAPPETT P.S.K.; LIU Y. Hydrogeochemical evolution along groundwater flow paths in the Manas River Basin, Northwest China. Groundwater, 57:575589, 2018 https://doi.org/10.1111/gwat.12829 
ZAIDI F.K.; NAZZAL Y.; JAFRI M.K.; NAEEM M.; AHMED I. Reverse ion exchange as a major process controlling the groundwater chemistry in an arid environment: a case study from northwestern Saudi Arabia. Environmental Monitoring and Assessment, 187:607, 2015 https://doi.org/10.1007/s10661-015-4828-4 